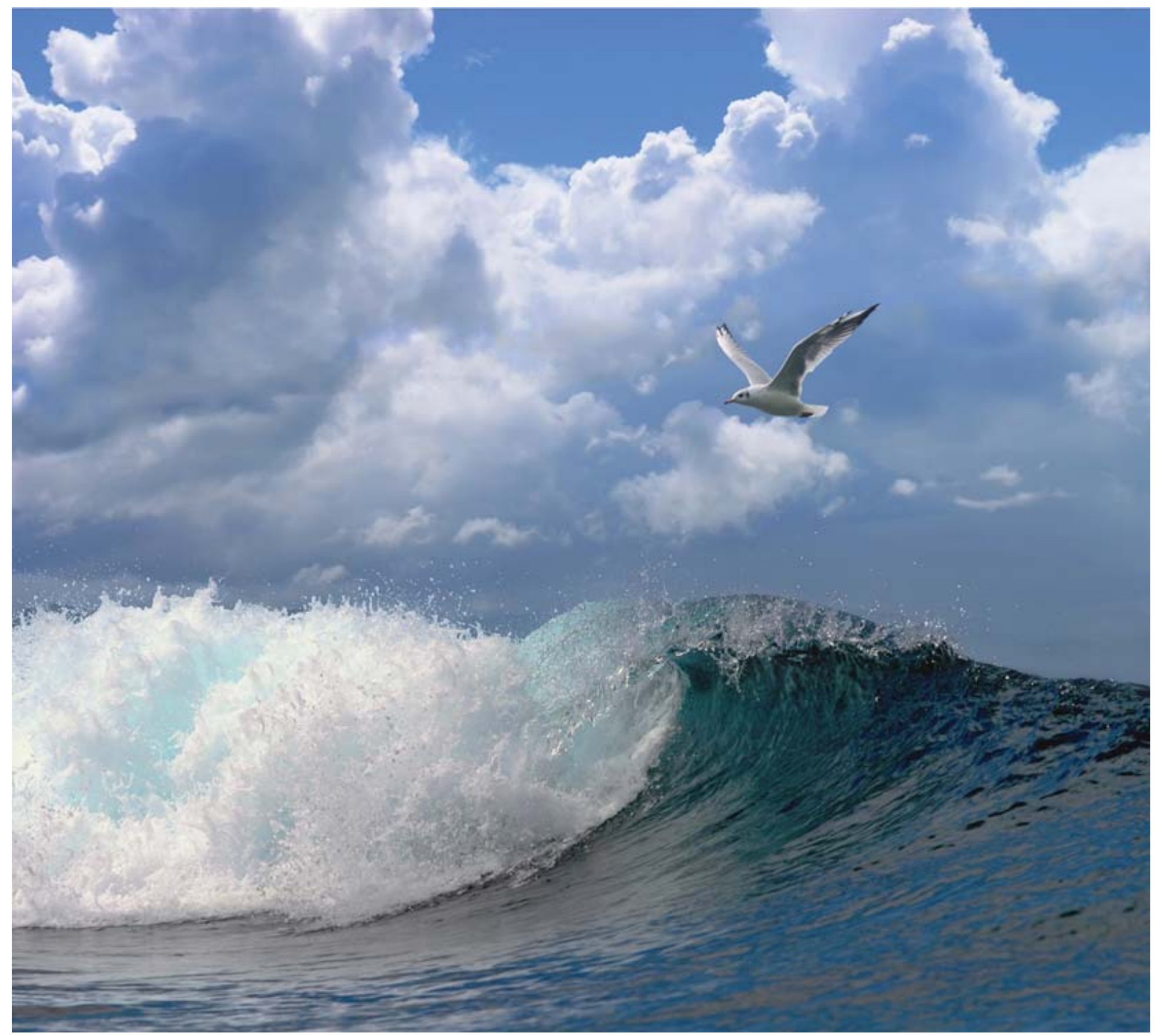

\title{
Effecten van nanoplastics in het mariene milieu getest in mesocosms
}





\section{Effecten van nanoplastics in het mariene milieu getest in mesocosms}

Auteur(s): $\quad$ E.M. Foekema, D.M.E. Slijkerman, C. Sonneveld, B.E. van der Weide, Y. Wei

Publicatiedatum 14 december 2017 
E.M. Foekema, D.M.E. Slijkerman, C. Sonneveld, B.E. van der Weide, Y. Wei, 2017. Effecten van nanoplastics in het mariene milieu getest in mesocosms, . Wageningen Marine Research Wageningen UR (University \& Research centre), Wageningen Marine Research rapport C107/17. 44 blz.;

Keywords: nanoplastic, microplastic, mesocosm, ecosysteem, effect.

Opdrachtgever: Rijkswaterstaat WVL

Postbus 17

8200 AA Lelystad

(WVL-Aanbestedingsdocumenten@rws.nl)

(zaaknr 31126160)

Dit rapport is gratis te downloaden van https://doi.org/10.18174/429280

Wageningen Marine Research verstrekt geen gedrukte exemplaren van rapporten.

Wageningen Marine Research Wageningen UR is ISO 9001:2008 gecertificeerd.

(C) 2017 Wageningen Marine Research

onderdeel van Stichting DLO.

KvK nr. 09098104,

BTW nr. NL 8113.83.696.B16.

Code BIC/SWIFT address: RABONL2U

IBAN code: NL 73 RABO 0373599285
De Directie van Wageningen Marine Research is niet aansprakelijk voor gevolgschade, noch voor schade welke voortvloeit uit toepassingen van de resultaten van werkzaamheden of andere gegevens verkregen van Wageningen Marine Research; opdrachtgever vrijwaart Wageningen Marine Research van aanspraken van derden in verband met deze toepassing.

Dit rapport is vervaardigd op verzoek van de opdrachtgever hierboven aangegeven en is zijn eigendom. Niets uit dit rapport mag weergegeven en/of gepubliceerd worden, gefotokopieerd of op enige andere manier gebruikt worden zonder schriftelijke toestemming van de opdrachtgever. 


\section{Inhoud}

$\begin{array}{ll}\text { Summary } & 4\end{array}$

$1 \quad$ Inleiding $\quad 5$

1.1 Afbakening 6

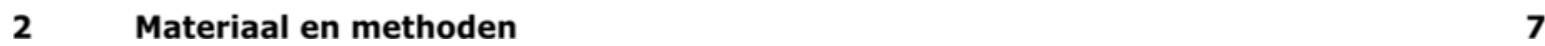

$\begin{array}{llr}2.1 & \text { Onderzoeksmethode } & 7\end{array}$

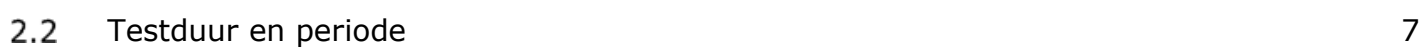

$\begin{array}{ll}2.3 & \text { Inrichting mesocosms }\end{array}$

2.3.1 Technische inrichting $\quad 7$

$\begin{array}{lll}2.3 .2 \text { Biota } & 8\end{array}$

$\begin{array}{lll}2.4 & \text { Teststoffen en behandelingen } & 9\end{array}$

2.4.1 Nanodeeltjes 9

$\begin{array}{ll}2.4 .2 & \text { Testconcentraties } \\ 2.4 .3 & 10\end{array}$

$\begin{array}{ll}2.4 .3 & \text { Dosering }\end{array}$

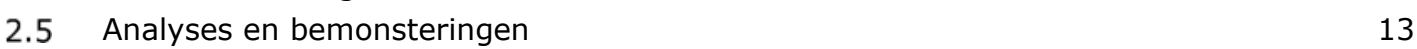

2.5.1 Fysische waterparameters 13

2.5.2 Biologische parameters 13

$\begin{array}{ll}\text { 2.5.3 Statistische interpretatie van de data } & 14\end{array}$

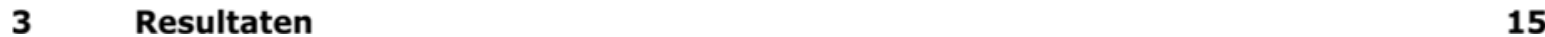

$3.1 \quad$ Algemene waterparameters $\quad 15$

3.1.1 Watertemperatuur $\quad 15$

$\begin{array}{lll}3.1 .2 & \text { Saliniteit } & 16\end{array}$

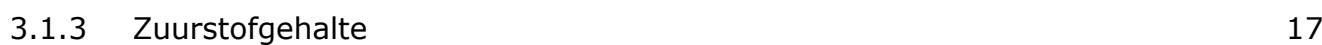

$\begin{array}{lll}3.1 .4 & \mathrm{pH} & 18\end{array}$

3.1.5 Troebelheid $\quad 19$

$\begin{array}{ll}3.1 .6 & \text { Nutriënten }\end{array}$

3.2 Biologische resultaten $\quad 21$

$\begin{array}{lll}3.2 .1 & \text { Phytoplankton } & 21\end{array}$

$\begin{array}{ll}3.2 .2 \text { Zooplankton } & 22\end{array}$

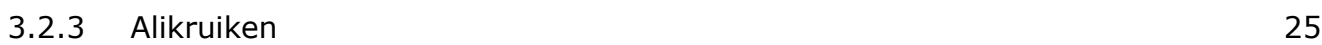

$\begin{array}{ll}3.2 .4 & \text { Mosselen }\end{array}$

$\begin{array}{lll}3.2 .5 & \text { Kokkels } & 26\end{array}$

$\begin{array}{lll}3.2 .6 & \text { Sponzen } & 27\end{array}$

3.2.7 Zeepieren 28

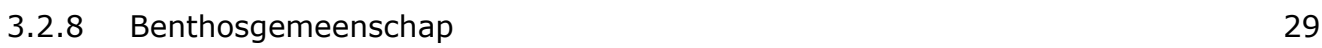

$\begin{array}{lll}3.3 & \text { Principal component analyse } & 31\end{array}$

$4 \quad$ Discussie en conclusies $\quad 33$

$5 \quad$ Kwaliteitsborging $\quad 35$

$6 \quad$ Financiële verantwoording 36

$\begin{array}{lr}\text { Literatuur } & 37\end{array}$

$\begin{array}{lr}\text { Verantwoording } & 38\end{array}$

Bijlage 1 Production of two batches polystyrene nanoparticles in request of Marine Research 


\section{Summary}

The ecological impact of nano-sized polystyrene particles was tested in marine outdoor mesocosms consisting of a pelagic and benthic compartment. Each mesocosm had a volume of approximately 2.5 $\mathrm{m}^{3}$ (approx. diameter $2 \mathrm{~m}$, depth $0.9 \mathrm{~m}$ ) and was installed with a $15 \mathrm{~cm}$ fine sand layer, covered with natural seawater containing a natural plankton community. A meiobenthic community was inoculated by means of an amount of sediment collected from the top layer in a tidal flat area.

Macroinvertebrates (lugworms, cockles, mussels, periwinkles, sponges, mudshrimps and mudsnails) were added in known numbers to the mesocosms. In total 15 mesocosms were installed following the same procedure in order to minimise variation between systems as much as possible. The water column in each mesocosm was continuously bubbled with compressed air to stimulate gas exchange and mixing of the water column. The mesocosms were covered with a transparent lid as a protection from rainfall and birds and their droppings. During the establishment phase that lasted 42 days, the water was circulated between the 15 mesocosms in order to stimulate a similar development. After this establishment phase, the mesocosms were disconnected and the dosing phase commenced. This dosing phase lasted 10 days during which on a daily bases $10 \%$ of the intended total amount of nanoparticles was added in the water column. The test material consisted of two types of polystyrene particles. The only difference between the particles was that the KPS particles had a median diameter of $55 \mathrm{~nm}$ and had a negatively charged surface, while the ACVA particles were $46 \mathrm{~nm}$ in diameter and more neutral. Both particle types were administered in a low $(0.25 \mathrm{mg} / \mathrm{L})$ and a high $(5 \mathrm{mg} / \mathrm{L})$ final concentration. Due to the difference is diameter between the particles the ACVA-mesocosms must have received about $70 \%$ more particles than the KPS mesocosms with the same dosage.

In this way four treatments and one control situation, were created that were all tested in three-fold. After the final dosage the development of each mesocosm was monitored for the next 67 days. This monitoring involved physical water characteristics, development (abundance, species richness and biodiversity) of the plankton and the benthic community, and survival, growth and, where appropriate, condition index of the introduced macroinvertebrates. As no analytical technique is available at this moment to analyse nano-particles in natural samples, the fate/distribution of the nano-particles could not be monitored. Biota samples are stored to allow analyses in the future. Mussel tissue is available for histopathological analyses.

The highest dosage of both particle types did increase turbidity in the water column, that lasted for a few days after the final dosing.

None of the treatments had a severe impact on the experimental ecosystems, and only two subtle, but statistically significant, effects were observed at the end of the study. Both these effects were related to growth rate of macroinvertebrate species. Interestingly, the presence of the neutral ACVA particles correlated with reduced growth rate in the sediment dwelling lugworms, while in the mesocosms with the negatively charged KPS-particles the growth of the filter feeding cockles was reduced. In both situations, the growth rates were significantly reduced compared to the controls at both treatment levels.

Apart from these statistically significant differences, the dataset of both highest treatments contained indications for the onset of effects. This concerns a slightly longer phytoplankton peak at the end of the dosing phase, and lower species richness of the benthic community compared to the control mesocosms.

This study was initiated by the Dutch Ministry of Infrastucture and Water Management and funded by the European Maritime and Fisheries Fund (EMFF). 


\section{$1 \quad$ Inleiding}

De aanwezigheid van nano- en microplasticdeeltjes in zee krijgt steeds meer aandacht van onderzoekers, beleidsmakers en publiek. De afgelopen jaren is daarom veel onderzoek verricht naar de aanwezigheid en effecten van microplasticdeeltjes in het mariene milieu. Het onderzoek dat zich richt op de effecten van microplasticdeeltjes op organismen is veelal mechanistisch van aard, waarbij het effect van concentraties plasticdeeltjes op individuele soorten wordt vergeleken met een controle situatie zonder plastic. Wanneer de concentratie plasticdeeltjes hoog genoeg is zullen vrijwel altijd effecten aangetoond kunnen worden. In veel gevallen liggen deze effectconcentraties substantieel hoger dan wat in het (zee)milieu wordt aangetroffen. In het geval van nanoplastics is dit onduidelijk, omdat het met de huidige technieken nog niet mogelijk is om de aanwezigheid van nanoplastics in milieumonsters aan te tonen.

Terwijl in dergelijke proeven effecten aan de plasticdeeltjes worden toegeschreven, blijft veelal onduidelijk in hoeverre de gevonden effecten specifiek zijn voor de aanwezigheid van plasticdeeltjes of het gevolg zijn van veranderingen (vertroebeling, verhoogde dichtheden oneetbaar gesuspendeerd materiaal) die ook kunnen worden veroorzaakt door natuurlijke materialen. Sowieso is de vertaalbaarheid van single-species laboratorium testen naar de veldsituatie zeer beperkt. Het gedrag van plastic deeltjes, zoals samenklontering met gesuspendeerde deeltjes, aangroei door microorganismen en sedimentatie zal in de veldsituatie anders verlopen dan in een laboratorium opstelling.

Op verzoek van RWS, met financiering vanuit het European Maritime and Fisheries Fund (EMFF) is in het voorjaar van 2017 door Wageningen Marine Research onderzoek verricht naar de effecten van nanoplastic deeltjes in mariene experimentele ecosystemen (mesocosms). Mesocosms zijn experimentele opstellingen waarin onderdelen van een ecosysteem op kleine schaal nagebootst worden. De systemen worden ingezet om bijvoorbeeld toxische stoffen te beoordelen op hun ecologische consequenties, waarbij ook de samenhang tussen organismen en hun onderlinge relaties kunnen worden gevolgd.

Het voordeel van een mesocosmstudie boven een laboratoriumtest met één soort, is dat interacties tussen soorten onderling en tussen organismen en hun omgeving in een mesocosm ook een rol spelen. Bovendien zullen de nanodeeltjes zich in een mesocosm-situatie meer natuurgetrouw gedragen dan in een bekerglas in een laboratorium.

Ten opzichte van veldonderzoek hebben mesocosms het voordeel dat de omstandigheden gecontroleerd kunnen worden, behandelingen kunnen worden gerepliceerd, en er sprake is van echte controle situaties. Mesocosms vervullen daardoor al jaren een brugfunctie bij de vertaling van laboratoriumgegevens naar de veldsituatie en spelen op deze wijze een prominente rol bij het Europese beoordelingsbeleid van biociden (de Jong et al., 2008).

De oorspronkelijke doelstelling van het project was om in de mesocosms voor verschillende organismen en ecologische processen de effecten van nano-/microplasticdeeltjes te vergelijken met de effecten van natuurlijke materialen zoals kleideeltjes, met zoveel mogelijk vergelijkbare eigenschappen.

$\mathrm{Na}$ een uitgebreide inventarisatie bleek het in de praktijk niet (nano-formaat), of slechts tegen extreem hoge kosten (micro-formaat), mogelijk om plastic- en kleideeltjes van vergelijkbare grootteverdeling te verkrijgen. Bovendien ontstond discussie tussen betrokken deskundigen en afgevaardigden van de opdrachtgever over de invloed van de fysische verschillen tussen klei en plastic op de onderzoeksresultaten qua absorberend vermogen, lading en soortelijk gewicht. Door deze verschillen zullen kleideeltjes zich op een totaal andere wijze in het systeem gedragen dan plastic deeltjes waardoor niet te onderscheiden is of eventuele verschillen in de ecologische impact puur het gevolg zijn van verschillen in het gedrag, zoals klontering, uitzakken, vertroebeling, of door verschillen in materialen worden veroorzaakt.

In laboratoriumstudies is gebleken dat lading van een nanodeeltje een belangrijke rol speelt bij het al dan niet optreden van biologische effecten. Onduidelijk is of deze verschillen ook optreden in de 
veldsituatie, of in experimentele ecosystemen, waar de deeltjes niet kunstmatig in suspensie worden gehouden. In overleg met de opdrachtgever is vervolgens besloten het onderzoek uit te voeren met twee typen polystyreen deeltjes van ca $50 \mathrm{~nm}$ die van elkaar verschillen door de lading van het oppervlak.

\section{$1.1 \quad$ Afbakening}

Nano- en microplastics kunnen in het milieu in veel verschillende verschijningsvormen aanwezig zijn door verschillen in grootte, vorm en materiaal. De onderzoeksresultaten van de hier gepresenteerde studie zullen specifiek zijn voor de gebruikte materialen, en indicatief voor andere vormen van plasticdeeltjes. Er kunnen geen specifieke uitspraken worden gedaan over het risico van plasticsoorten, -vormen of -grootteklassen die niet zijn onderzocht.

Dit onderzoek richt zich uitsluitend op de biologische effecten van de deeltjes. Analyse van plastics in de range van $1 \mu \mathrm{m}(1000 \mathrm{~nm})$ en kleiner in natuurlijke monsters was ten tijde van de uitvoering van het experiment technisch niet mogelijk en vormt daarom ook geen onderdeel van dit project. Wel zijn monsters verzameld en opgeslagen voor eventuele analyse in de toekomst. Deze monsters zullen in elk geval 2 jaar, dus tot 2019 bewaard worden. 


\section{Materiaal en methoden}

\subsection{Onderzoeksmethode}

Het onderzoek is uitgevoerd in 15 model ecosystemen ('mesocosms'), elk met een volume van ca 2.5 $\mathrm{m}^{3}$ warin een deel van een Nederlands marien ecosysteem is nagebootst.

Voor dit onderzoek is een ecosysteem opgebouwd bestaande uit een plankton- en benthosgemeenschap. Met water en sediment zijn plankton en kleine bodemorganismen in de mesocosms gebracht, en zijn invertebraten van verschillende taxonomische groepen (schelpdieren, wormen, kreeftachtigen en sponzen) in bekende hoeveelheden in de mesocosm geïntroduceerd ${ }^{1}$. Gedurende een acclimatisatieperiode van enkele weken ontwikkelt zich vervolgens in elke mesocosm een vergelijkbaar mini-ecosysteem, waarna de experimentele behandeling start, in dit geval met het gedurende 10 dagen doseren van de nanodeeltjes. De ontwikkeling van de ecosystemen is vervolgens gedurende 10 weken gevolgd, zoals hieronder in meer detail wordt beschreven.

\subsection{Testduur en periode}

De studie werd uitgevoerd in de periode van 29 maart tot 18 juli 2017. Omdat de biologische productie in het voorjaar maximaal is, is dit de meest gevoelige periode om effecten aan te tonen in outdoor mesocosm studies.

Op 29 maart, nadat sediment en water was aangebracht, startte de acclimatisatieperiode waarin het water tussen alle mesocosms werd gecirculeerd. Gedurende het eerste deel van deze periode werden organismen in de mesocosms uitgezet. De acclimatisatieperiode werd na 42 dagen, op 10 mei beëindig door het loskoppelen van de mesocosms.

Tussen 10 en 19 mei, gedurende 10 dagen zijn dagelijks nanodeeltjes gedoseerd. Daarna zijn de ontwikkelingen in de mesocosms gevolgd totdat op 18 juli de laatste bemonstering werd uitgevoerd. De bloostellingsperiode vanaf de start van de dosering bedroeg dus 67 dagen.

\subsection{Inrichting mesocosms}

\subsubsection{Technische inrichting}

De mesocosms zijn voor deze studie ingericht in polyester tanks met een diameter van ca. 2 meter en een totaal volume van ca. $2.5 \mathrm{~m}^{3}$ opgesteld op het buitenterrein van Wageningen Marien Research in Den Helder. Bij aanvang van de studie zijn alle mesocosms op exact dezelfde wijze ingericht. Op de bodem van elke tank is op 8 april een $15 \mathrm{~cm}$ dikke laag fijn Noordzee zand aangebracht, waarna de tanks werden gevuld met natuurlijk zeewater tot een waterdiepte van ca. $80 \mathrm{~cm}$ was bereikt. Het zeewater was dezelfde dag ingenomen in de Oosterschelde en naar Den Helder getransporteerd met een tankwagen.

De waterkolom in de mesocosms werd gedurende de gehele studie continue belucht met behulp van een bruissteen op ca $10 \mathrm{~cm}$ boven het sedimentoppervlak in het centrum van elke mesocosm. Deze wijze van beluchten leidt tot een continue homogene menging van de waterkolom.

Om verstoring van het systeem door regenval, vogelpoep of andere factoren van buitenaf zoveel mogelijk te voorkomen was elke mesocosm voorzien van een transparante (polycarbonaat) deksel, gemonteerd op ca $30 \mathrm{~cm}$ boven elke mesocosm. Deze deksels laten ruim $90 \%$ van het zonlicht door, zodat natuurlijke processen niet worden belemmerd. Door de deksels op boven de mesocosms te monteren werd een 'broeikas-effect' voorkomen.

\footnotetext{
${ }^{1}$ Soorten die een grote invloed hebben op een dergelijk klein model ecosysteem, zoals vissen en grotere invertebrate predatoren (zeesterren, krabben) worden in mesocosm onderzoek in principe vermeden, tenzij er een specifieke reden is dergelijke soorten wel mee te nemen, zoals bijvoorbeeld in biomagnificatie onderzoek.
} 


\subsubsection{Biota}

De systemen werden tijdens het vullen met ongefilterd, vers Oosterschelde water geënt met een natuurlijke planktongemeenschap. Om een benthische levensgemeenschap te creëren, is tijdens laagwater ca. 60 liter slib (oppervlaktelaag) verzameld in de Waddenzee langs de kust van Wieringen. Dit sediment is gezeefd over een $5 \mathrm{~mm}$ zeef om grof materiaal en grotere organismen te verwijderen. Vervolgens is deze partij slib goed gemengd en in gelijke delen verdeeld over de 15 mesocosms. Per mesocosm is ruim 3 liter slib toegevoegd. Dit is voldoende voor het enten van benthische diatomeeën, micro-organismen en meiofauna.

In aanvulling hierop zijn een aantal grotere soorten in bekende aantallen in de mesocosms geplaatst. Deze organismen werden kort daarvoor in de Waddenzee verzameld.

Slijkgarnalen (ca. 150 per mesocosm), zeepieren (20 per mesocosm) en kokkels (25 per mesocosm) zijn dominante soorten van een zachte (zand)bodem in een getijdengebied en hebben door hun graafactiviteiten (bioturbatie) een belangrijke rol bij het structureren van de bodem en de ontwikkeling van de benthische levensgemeenschap (Figuur 1). Alikruiken (50 per mesocosm) zijn de belangrijkste begrazers van harde substraten en zijn ingezet om de aangroei van macroalgen op de wanden van de mesocosms onder controle te houden. De benthische organismen zijn voor dag -25 in de mesocosms gebracht.

In aparte enclosures ${ }^{2}$ zijn 30 jonge mosselen (Mytilus edulis) en 3 stukjes broodspons (Halichondria panicea) op halve waterdiepte in de mesocosms gehangen. De jonge mosselen waren afkomstig van een mosselperceel in de Oosterschelde. Uit de verzamelde partij zijn onbeschadigde exemplaren van ca. $3 \mathrm{~cm}$ lengte geselecteerd en vervolgens at random verdeeld in groepjes van 30 exemplaren. Deze groepjes mosselen werden verpakt in kunststof netjes. De gemiddelde schelplengte van de ingezette mosselen was $23.6 \pm 0.5 \mathrm{~mm}$.

De ingezette sponzen waren ook afkomstig van de mosselpercelen in de Oosterschelde. Grote gezonde exemplaren werden in stukken gesneden van zoveel mogelijk gelijke grootte. Na weging zijn deze stukken spons in netjes verpakt en in de waterkolom van de mesocosms gehangen. Elke mesocosm 'ontving' 3 stukjes spons elk met een gemiddeld gewicht van $40 \pm 8$ gram.

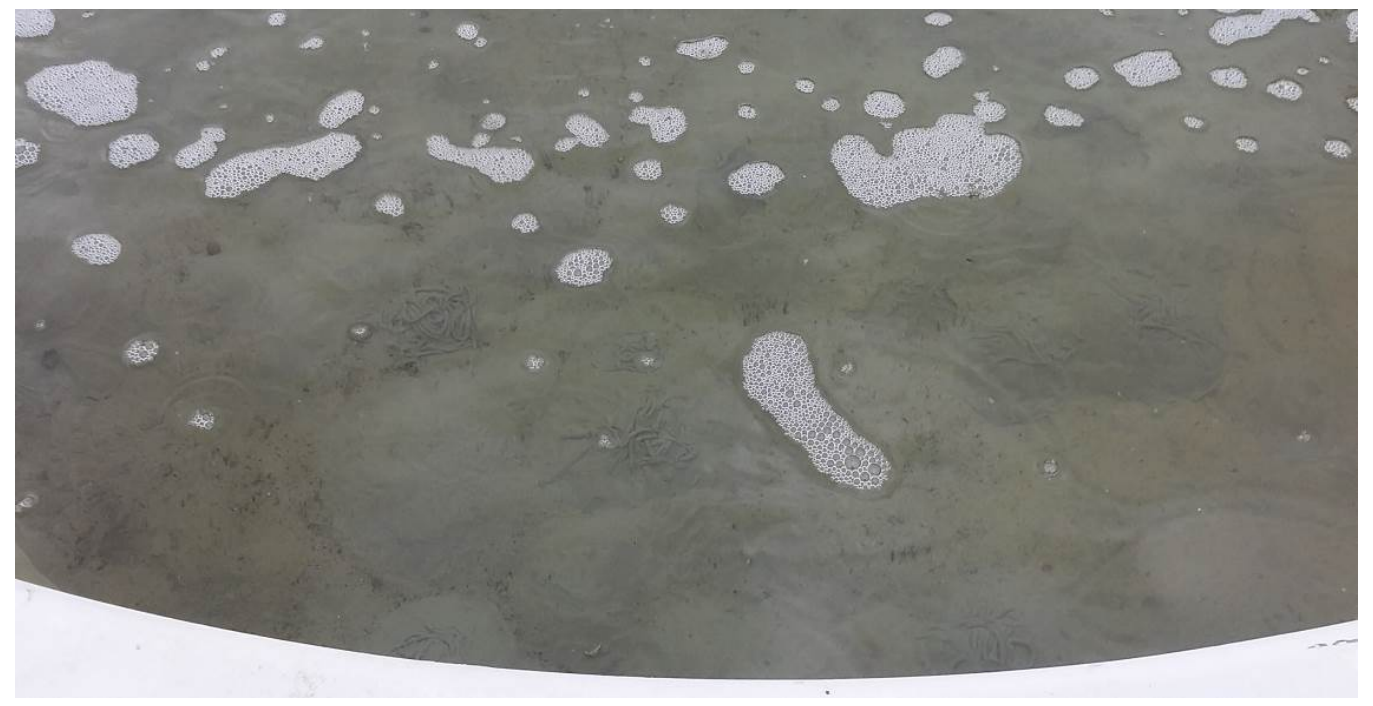

Figuur 1 De bodem van één van de mesocosms, gefotografeerd tijdens de acclimatisatieperiode. De invloed van de zeepieren op de bodemstructuur is duidelijk zichtbaar.

\footnotetext{
${ }^{2}$ In deze studie: kunststof netjes om de dieren bij elkaar te houden
} 


\subsection{Teststoffen en behandelingen}

\subsubsection{Nanodeeltjes}

De toegepaste nanodeeltjes zijn geproduceerd bij Wageningen Food \& Biobased Research. De deeltjes werden gepolymeriseerd uit styreen volgens de procedure die is beschreven in de bijlage. De chemicaliën vermeld in tabel 2 werden hierbij gebruikt. Er zijn twee soorten deeltjes geproduceerd waarbij als initiator respectievelijk kaliumpersulfaat (KPS) of 4,4'-Azobis (4-cyanovaleric acid) (ACVA) is toegepast. KPS resulteert in negatief geladen deeltjes, terwijl de met ACVA geproduceerde deeltjes een meer neutrale lading hebben. De deeltjes worden in dit rapport verder aangeduid als ACVA en KPS. De diameter van de ACVA deeltjes bedroeg $46 \pm 1 \mathrm{~nm}$, van de KPS deeltjes was dit $55 \pm 9 \mathrm{~nm}$ (Figuur 2).

De deeltjes werden geleverd in een emulsie met daarin ca. 35\% deeltjes in gedemineraliseerd water (Tabel 2). Om klontering van de deeltjes te voorkomen bevatte de emulsie een minimale hoeveelheid (1\%) van de surfactant Natriumdodecylsulfaat (SDS; Sodium dodecyl sulfate).

Tabel 1 Chemicaliën die zijn gebruikt bij de productie van de suspensies met polystyreen nanodeeltjes

\begin{tabular}{|l|l|l|}
\hline Chemicaliën & Leverancier & Purity (\% ) \\
\hline Styrene & Sigma Aldrich & $\geq 99$ \\
$4,4^{\prime}$-Azobis (4-cyanovaleric acid) (ACVA) & Sigma Aldrich & $\geq 98$ \\
Kalium persulfaat (KPS) & Acros organics & $\geq 99$ \\
Sodium dodecyl sulfate (SDS) & Sigma Aldrich & $\geq 99$ \\
Sodium bicarbonate & Alfa Aesar & 99 \\
Natronloog $(\mathrm{NaOH})$ & Sigma Aldrich & $\geq 99$ \\
\hline
\end{tabular}

Tabel 2 Samenstelling van de emulsies van nanodeeltjes die werden gebruikt voor de dosering

\begin{tabular}{|l|l|l|}
\hline Component & \multicolumn{2}{|c|}{ Gewichtspercentage } \\
& ACVA & KPS \\
\hline Polystyreen nanodeeltjes & $34.6 \%$ & $35.9 \%$ \\
Gedemineraliseerd Water & $64.1 \%$ & $62.8 \%$ \\
Sodium dodecyl sulfate (SDS) & $1.0 \%$ & $1.0 \%$ \\
Natrium bicarbonaat & $0.22 \%$ & $0.22 \%$ \\
Natronloog & $<0.1 \%$ & $<0.1 \%$ \\
\hline
\end{tabular}




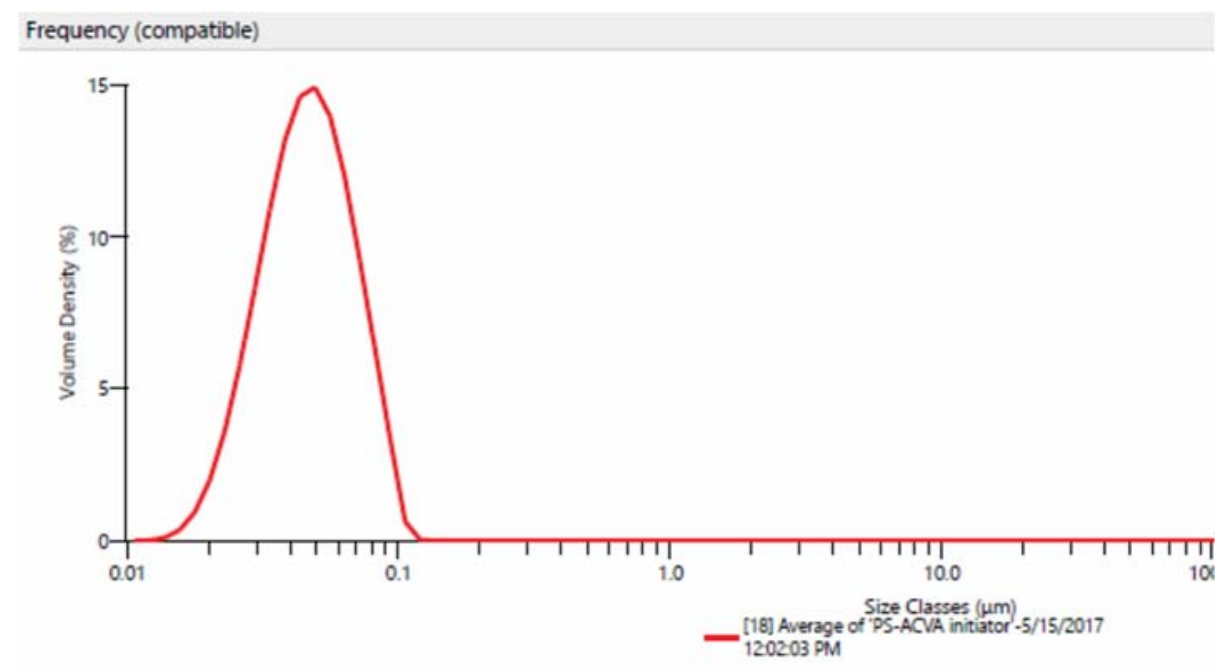

Frequency (compatible)

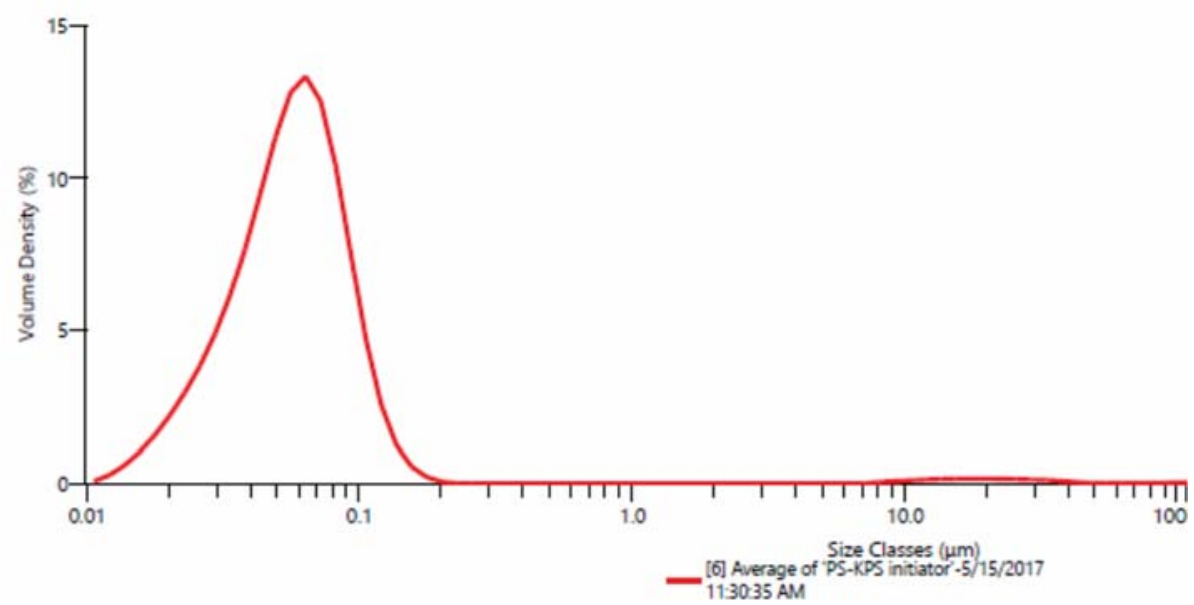

Figuur 2 Grootteverdeling van de gebruikte nanodeeltjes Boven: ACVA ( $46 \pm 1 \mathrm{~nm})$; Onder KPS (55 \pm 9 $\mathrm{nm})$

\subsubsection{Testconcentraties}

Omdat het op dit moment nog niet mogelijk is om plastic nanodeeltjes in het milieu te identificeren en te kwantificeren waren er geen veldgegevens beschikbaar om de blootstellingsconcentraties op te baseren. Er zijn wel gegevens beschikbaar over grotere (micro-)plastic deeltjes. In Tabel 3 is ter indicatie een overzicht gegeven van de maximaal gerapporteerde aantallen microplastic deeltjes in het marine milieu.

Tabel 3 Maximale aantallen deeltjes micro-plastics (in elk geval $>65 \mu \mathrm{m}$ ) gerapporteerd voor verschillende regio's (gegevens uit GESAMP, 2015 aangevuld met Frias et al.,2014, Desforges et al.,2014 en Cózar et al.,2017). De datasets waarvoor alleen aantallen per $\mathrm{km}^{2}$ werden gerapporteerd zijn ter indicatie omgerekend naar aantallen per $\mathrm{m}^{3}$ met de aanname dat er een waterdiepte van $10 \mathrm{~cm}$ werd bemonsterd $\left(1 \mathrm{~km}^{2}=100.000 \mathrm{~m}^{3}\right)$.

\begin{tabular}{|lcl|}
\hline Locatie & $\mathbf{n} / \mathbf{~ m}^{\mathbf{3}}$ & Referentie \\
\hline North Sea & 0.05 & Thompson et al., 2004 \\
Western North Atlantic & 14.1 & Carpenter \& Smith, 1972 \\
Eastern North Atlantic & 0.116 & Collignon et al., 2014 \\
Mediterranean Sea & 0.94 & Fossi et al., 2012 \\
Western North Atlantic & 0.04 & Frias et al., 2014 \\
North Eastern Pacific & 9180 & Desforges et al., 2014 \\
\hline
\end{tabular}


Een opvallende uitschieter vormt de dataset van Desforges et al. (2014) die meer dan 9000 plastic deeltjes per $\mathrm{m}^{3}$ aantroffen in de Noordoost Pacific, in een zogenaamde 'gyre' waarin organisch materiaal en plastic 'gevangen' zit in een ronddraaiende stroming. In dit onderzoek is een fijner net (65 micrometer) gebruikt dan bij de andere studies (doorgaans ca 300 micrometer). Dit suggereert dat kleinere plastic deeltjes in grotere aantallen aanwezig zijn. Er zijn echter geen gegevens bekend over de aanwezigheid van plastic deeltjes kleiner dan 65 micrometer in zee, en de allerkleinste (nano) deeltjes zijn technisch nog niet aan te tonen in milieumonsters.

De absoluut maximale hoeveelheid microplastics die ooit in veldmonsters zijn gerapporteerd bedroeg 102 deeltjes $>80 \mu \mathrm{m}$ per Liter (Lozano \& Mouat 2009). Dit betrof een (zoetwater) locatie in de nabijheid van een polyethyleen fabriek en deze situatie kan daarom als worst case worden beschouwd. Deze worst case situatie is gebruikt om de blootstellingsconcentratie voor deze studie te bepalen. Wanneer wordt aangenomen dat alle gevonden deeltjes perfecte bollen zijn (=overschatting van volume), met een diameter van $80 \mu \mathrm{m}$ diameter (=onderschatting van grootte) en bestaan uit polystyreen met een soortelijk gewicht van $1.05 \mathrm{~g} / \mathrm{cm}^{3}$ dan is de waterconcentratie $0.23 \mathrm{mg} / \mathrm{L}$. Deze concentratie is in deze studie als de lage testconcentratie gehanteerd.

De hoge test concentratie is 20 maal hoger gekozen $(5 \mathrm{mg} / \mathrm{L}$ ) en kan dus als een extreme situatie worden beschouwd. Bij hogere concentraties ontstaat naar verwachting een substantiële vertroebeling van het water wat tot indirecte effecten aanleiding kan geven.

In alle mesocosms inclusief de controles is een gelijke hoeveelheid van de surfactant SDS gedoseerd, zodat de eindconcentratie SDS in alle mesocosms $0.1 \mathrm{mg} / \mathrm{L}$ bedroeg. Op basis van bestaande informatie is het zeer onwaarschijnlijk dat deze SDS concentratie tot effecten zal leiden (Radix et al. 1999; Lurling et al. 2002).

\subsubsection{Dosering}

De 15 mesocosms stonden opgesteld in 3 rijen van 5 . Volgens het principe van een 'random block design' werden de vijf verschillende behandelingen in 3-voud at random per rij verdeeld. De verdeling van de behandelingen over de mesocosms en de codes waarmee de behandelingen in dit rapport zullen worden aangeduid zijn weergegeven in Tabel 4.

Vanaf dag 0 is gedurende 10 dagen dagelijks $10 \%$ van de te doseren hoeveelheid suspensie in de mesocosms gedoseerd. Voor elke behandeling werd $60 \mathrm{ml}$ stockoplossing gemaakt. De stockoplossing voor de hoogste testconcentraties bestond volledig uit de suspensie waarin de nanodeeltjes zijn geleverd en die $1 \%$ SDS bevatte. De stockoplossing voor de lage testconcentraties bestonden uit de benodigde hoeveelheid suspensie aangevuld met gedemineraliseerd water met $1 \%$ SDS. De stockoplossing voor de controles bestond volledig uit gedemineraliseerd water met $1 \%$ SDS. Tijdens de 10 dagen durende doseerperiode werd dagelijks voor elke mesocosm $5 \mathrm{ml}$ van de 'eigen' stockoplossing gemengd met ca 1 liter mesocosm water in een bekerglas. De inhoud van dit bekerglas werd vervolgens in de beluchtingsstroom van de mesocosms gegoten, waardoor snelle menging door de waterkolom plaatsvond (Figuur 3).

Tabel 4 Overzicht van de behandelingen, de verdeling van de behandelingen over de mesocosms en de codes waarmee de behandelingen in dit rapport worden aangeduid.

\begin{tabular}{|l|l|l|}
\hline Behandeling & Mesocosm codes & Rapportage code \\
\hline Controle & M4, M6, M11 & Controle \\
ACVA-deeltjes eindconcentratie $0.25 \mathrm{mg} / \mathrm{L}$ & $\mathrm{M1}, \mathrm{M} 10, \mathrm{M} 14$ & ACVA-1 \\
ACVA-deeltjes eindconcentratie $5 \mathrm{mg} / \mathrm{L}$ & $\mathrm{M} 2, \mathrm{M} 9, \mathrm{M} 15$ & ACVA-2 \\
KPS-deeltjes eindconcentratie $0.25 \mathrm{mg} / \mathrm{L}$ & $\mathrm{M} 5, \mathrm{M} 8, \mathrm{M} 12$ & KPS-1 \\
KPS-deeltjes eindconcentratie $5 \mathrm{mg} / \mathrm{L}$ & $\mathrm{M3}, \mathrm{M7}, \mathrm{M} 13$ & KPS-2 \\
\hline
\end{tabular}




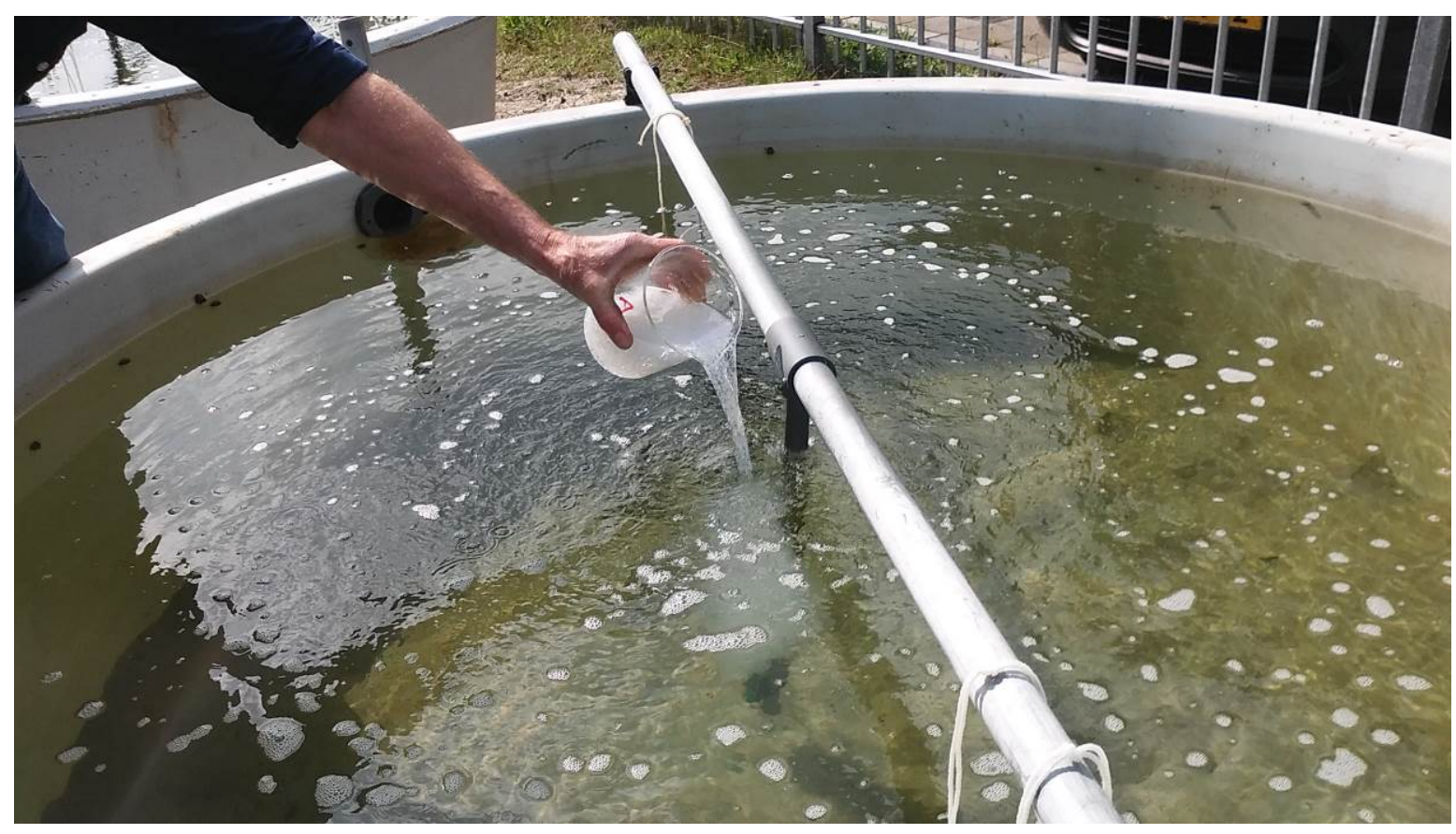

Figuur 3 De eerste dosering van één van de drie ACVA-2 mesocosms op 10 mei 2017. 


\subsection{Analyses en bemonsteringen}

Een overzicht van de uitgevoerde analyses en bemonsteringen is gegeven in Tabel 5. In de volgende paragrafen worden de handelingen toegelicht.

Tabel 5 Fasering van de studie en bemonsteringsschema. Water $=$ temperatuur, saliniteit, $\mathrm{pH}$, zuurstofgehalte; Troe = troebelheid; $\mathrm{Chl}=$ chlorophyl-a; N/P : nutriënten concentraties; Zoo=zoöplankton gemeenschap; Fyto = fytoplankton gemeenschap; Mos = mossel overleving; Spons $=$ spons overleving en groei; Benthos $=$ benthos gemeenschap .

\begin{tabular}{|c|c|c|c|c|c|c|c|c|c|c|}
\hline Dagnr & Fase & Water & Troe & ChI & $\mathbf{N} / \mathbf{P}$ & Zoo & Fyto & Mos & Spons & Benthos \\
\hline-43 & Start & $\sqrt{ }$ & & & & & & & & \\
\hline-36 & Acclimatisatie & $\sqrt{ }$ & & & & & & & & \\
\hline-29 & Acclimatisatie & $\sqrt{ }$ & $\sqrt{ }$ & $\sqrt{ }$ & & & & & & \\
\hline-22 & Acclimatisatie & $\sqrt{ }$ & $\sqrt{ }$ & $\sqrt{ }$ & & & & & & \\
\hline-8 & Acclimatisatie & $\sqrt{ }$ & $\sqrt{ }$ & $\sqrt{ }$ & & & & & & \\
\hline-1 & Acclimatisatie & $\sqrt{ }$ & $\sqrt{ }$ & $\sqrt{ }$ & $\sqrt{ }$ & $\sqrt{ }$ & $\sqrt{ }$ & $\sqrt{ }$ & $\sqrt{ }$ & \\
\hline $\mathbf{0}$ & Dosering & & $\sqrt{ }$ & & & & & & & \\
\hline 1 & Dosering & & $\sqrt{ }$ & & & & & & & \\
\hline 2 & Dosering & & $\sqrt{ }$ & & & & & & & \\
\hline 4 & Dosering & $\sqrt{ }$ & $\sqrt{ }$ & $\sqrt{ }$ & & & & & & \\
\hline 5 & Dosering & & $\sqrt{ }$ & & & & & & & \\
\hline 6 & Dosering & $\sqrt{ }$ & $\sqrt{ }$ & $\sqrt{ }$ & & & & & & \\
\hline 7 & Dosering & & $\sqrt{ }$ & & & & & & & \\
\hline 8 & Dosering & & $\sqrt{ }$ & & & & & & & \\
\hline 9 & Dosering & & $\sqrt{ }$ & & & & & & & \\
\hline 11 & Blootstelling & & $\sqrt{ }$ & & & & & & & \\
\hline 13 & Blootstelling & $\sqrt{ }$ & $\sqrt{ }$ & $\sqrt{ }$ & & $\sqrt{ }$ & $\sqrt{ }$ & $\sqrt{ }$ & $\sqrt{ }$ & \\
\hline 20 & Blootstelling & $\sqrt{ }$ & $\sqrt{ }$ & $\sqrt{ }$ & & & & & & \\
\hline 27 & Blootstelling & $\sqrt{ }$ & $\sqrt{ }$ & $\sqrt{ }$ & & & & & & \\
\hline 34 & Blootstelling & $\sqrt{ }$ & $\sqrt{ }$ & $\sqrt{ }$ & $\sqrt{ }$ & $\sqrt{ }$ & $\sqrt{ }$ & $\sqrt{ }$ & $\sqrt{ }$ & \\
\hline 41 & Blootstelling & $\sqrt{ }$ & $\sqrt{ }$ & $\sqrt{ }$ & & & & & & \\
\hline 48 & Blootstelling & $\sqrt{ }$ & $\sqrt{ }$ & $\sqrt{ }$ & & & & & & \\
\hline 55 & Blootstelling & $\sqrt{ }$ & $\sqrt{ }$ & $\sqrt{ }$ & & & & & & \\
\hline 62 & Blootstelling & $\sqrt{ }$ & $\sqrt{ }$ & $\sqrt{ }$ & & & & & & \\
\hline 67 & Eind & $\sqrt{ }$ & $\sqrt{ }$ & $\sqrt{ }$ & $\sqrt{ }$ & $\sqrt{ }$ & $\sqrt{ }$ & $\sqrt{ }$ & $\sqrt{ }$ & $\sqrt{ }$ \\
\hline
\end{tabular}

\subsubsection{Fysische waterparameters}

Temperatuur, saliniteit, $\mathrm{pH}$, zuurstofgehalte en troebelheid van het water in de mesocosms is wekelijks bepaald op halve waterdiepte met behulp van Hach-Lange electrodes (HQ40D voor pH en zuurstof; HQ30D voor saliniteit en temperatuur). Tijdens de doseringsperiode zijn de troebelheidsmetingen met een hogere frequentie uitgevoerd.

Voor de bepaling van het gehalte van anorganisch stikstof $\left(\mathrm{NH}_{3}, \mathrm{NH}_{4}, \mathrm{NO}_{3}\right)$, ortho-fosfaat $\left(\mathrm{PO}_{4}\right)$ en silicaat $\left(\mathrm{SiO}_{2}\right)$ zijn op dag -1, 34 en 67 watermonsters uit de mesocosms verzameld op halve waterdiepte. De analyses van deze monsters werd uitgevoerd door Het Waterlaboratorium te Haarlem.

\subsubsection{Biologische parameters}

De ontwikkeling van de algenbiomassa in de waterkolom is wekelijks bepaald aan de hand van het chlorofyl-a gehalte in watermonsters die op halve waterdiepte zijn verzameld. Het chlorofyl-a gehalte werd direct in het monster bepaald met behulp van een BBE Moldaenke algae lab analyser (BBE, Duitsland). Deze analyzer geeft tevens een indicatie van de bijdrage van de belangrijkste phytoplanktongroepen aan het totale chlorofyl-a gehalte. 
Elke 14 dagen zijn monsters verzameld om de soortensamenstelling van de fytoplanktongemeenschap te bepalen. Deze monsters zijn ook op halve waterdiepte genomen en na conservering met $1 \%$ lugol opgeslagen. Deze monsters zijn beschikbaar voor eventuele analyse op een later tijdstip.

Op dag 14 en 35 werden de sponzen gewogen en de levende mosselen geteld.

Tijdens de eindbemonstering werden de hele mesocosms bemonsterd.

De benthosgemeenschap in de zandbodem is gekarakteriseerd aan de hand van twee sub-monsters. Deze zijn verzameld door een cilinder van $30 \mathrm{~cm}$ diameter en een oppervlak van $706 \mathrm{~cm}^{2}$ tot op de bodem door de zandlaag te drukken op het moment dat er nog enkele $\mathrm{cm}$ water in de mesocosm stond. De binnenzijde van de buis is vervolgens leeggeschept en over een $500 \mu \mathrm{m}$ zeef uitgespoeld om de aanwezige organismen te verzamelen. De organismen zijn geconserveerd op formaline en op een later tijdstip op soort gebracht en geteld. De geïntroduceerde mosselen, sponzen, alikruiken, kokkels en zeepieren werden verzameld om overleving, groei en conditie vast te stellen.

\subsubsection{Statistische interpretatie van de data}

De significantie van de verschillen tussen de behandelingen is statistisch getoetst met behulp van het software pakket GraphPad PRISM v7. De significantie van de verschillen tussen de behandelingen op de verschillende meettijdstippen is getoetst met een two-way-ANOVA test gevolgd door een Bonferroni multiple comparison test. Verschillen worden statistisch significant beschouwd bij $\mathrm{p}<0.05$. 


\section{Resultaten}

\subsection{Algemene waterparameters}

\subsubsection{Watertemperatuur}

De watertemperatuur in de mesocosms (Figuur 4) lag bij het begin van de doseringsperiode rond 11 ${ }^{\circ} \mathrm{C}$. Gedurende de studie steeg de temperatuur tot een maximale waarde van ca. $21^{\circ} \mathrm{C}$ rond dag 56. Dit is een normale temperatuurrange voor de Noordzee en zal de ontwikkeling van de systemen niet afwijkend hebben beïnvloed. Het temperatuursverloop was in alle mesocosms gelijk.

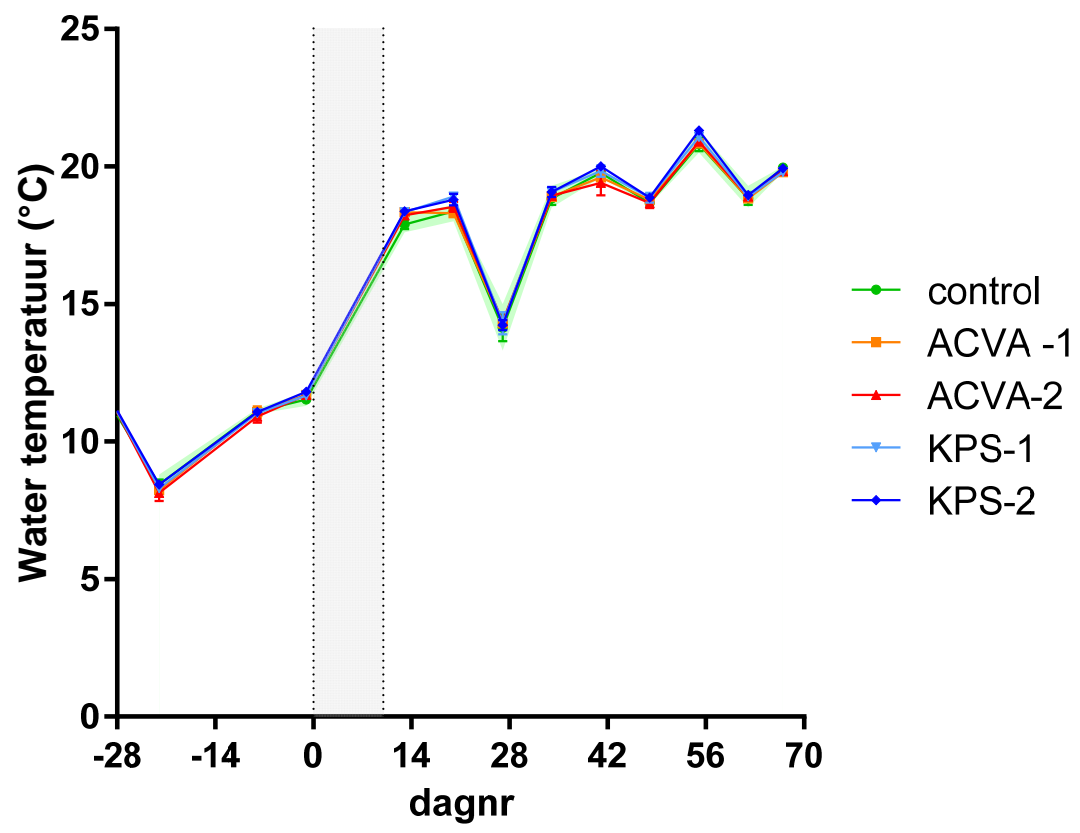

Figuur 4 Watertemperatuur in de mesocosms met verschillende behandelingen. Voor elke behandeling zijn de gemiddelden en de range van de waarnemingen van de drie replica's weergegeven. De range van de controle mesocosms is weergegeven als groen veld rond de lijn die de gemiddelde aarde aangeeft. De kolom geeft de doseringsperiode tussen dag 0 en 10 weer. 


\subsubsection{Saliniteit}

Het Oosterschelde water waarmee de mesocosms werden gevuld had een saliniteit van net geen $32 \%$. Gedurende de studie werd regelmatig gedemineraliseerd water aan de mesocosms toegevoegd om te compenseren voor verdamping. Dit is zichtbaar in de fluctuatie van de saliniteit in de tijd (Figuur 5). De hoogste saliniteit van net iets meer dan 36\%o werd gemeten rond dag 62. De in de mesocosms aanwezige organismen zijn goed bestand tegen deze saliniteitsrange. Bovendien zijn organismen uit getijdengebieden ook aan enige schommeling in saliniteit gewend. Tussen de mesocosms bestonden geen substantiële verschillen (Figuur 5).

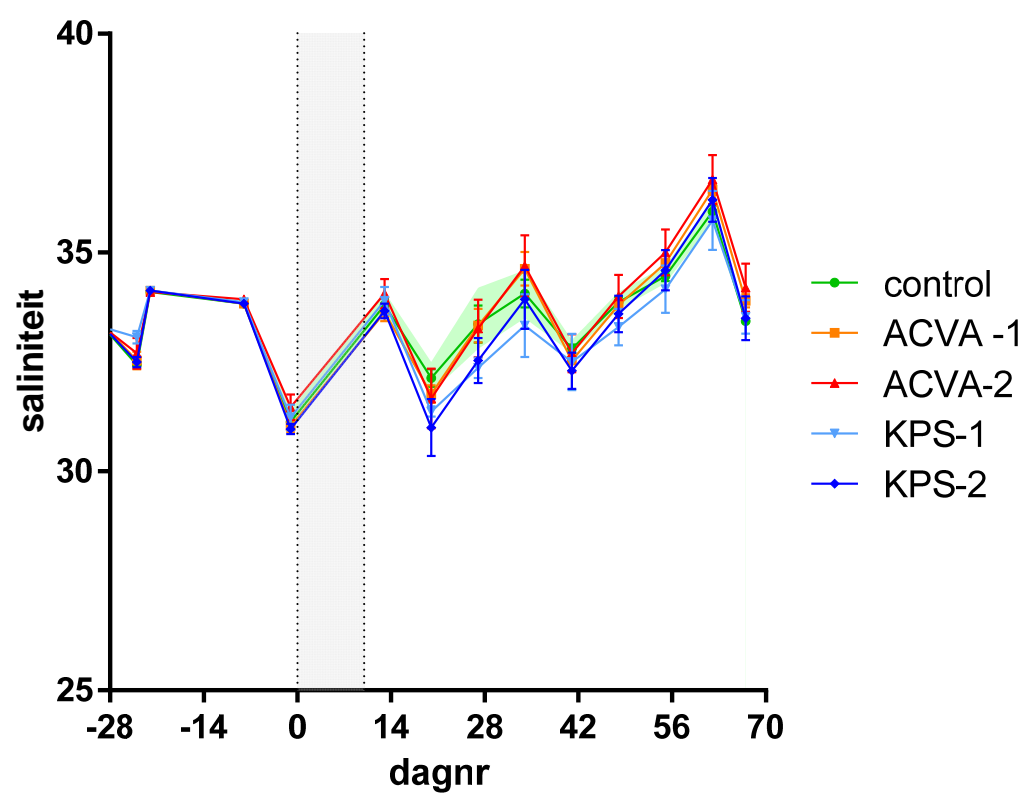

Figuur 5 Saliniteit van het mesocosm water met verschillende behandelingen. Voor elke behandeling zijn de gemiddelden en de range van de waarnemingen van de drie replica's weergegeven. De range van de controle mesocosms is weergegeven als groen veld rond de lijn die de gemiddelde aarde aangeeft. De kolom geeft de doseringsperiode tussen dag 0 en 10 weer. 


\subsubsection{Zuurstofgehalte}

De concentratie opgelost zuurstof in de waterkolom lag gedurende de gehele studie in alle mesocosms rond het maximale verzadigingsniveau (100\%; Figuur 6 ). Dit is mede het gevolg van de continue beluchting van de waterkolom. Fluctuaties in de tijd als gevolg van verandering van watertemperatuur en of verandering van instraling en daarmee van de primaire productie deden zich in alle mesocosms gelijktijdig voor. Er was dan ook geen sprake van substantiële verschillen tussen de mesocosms.

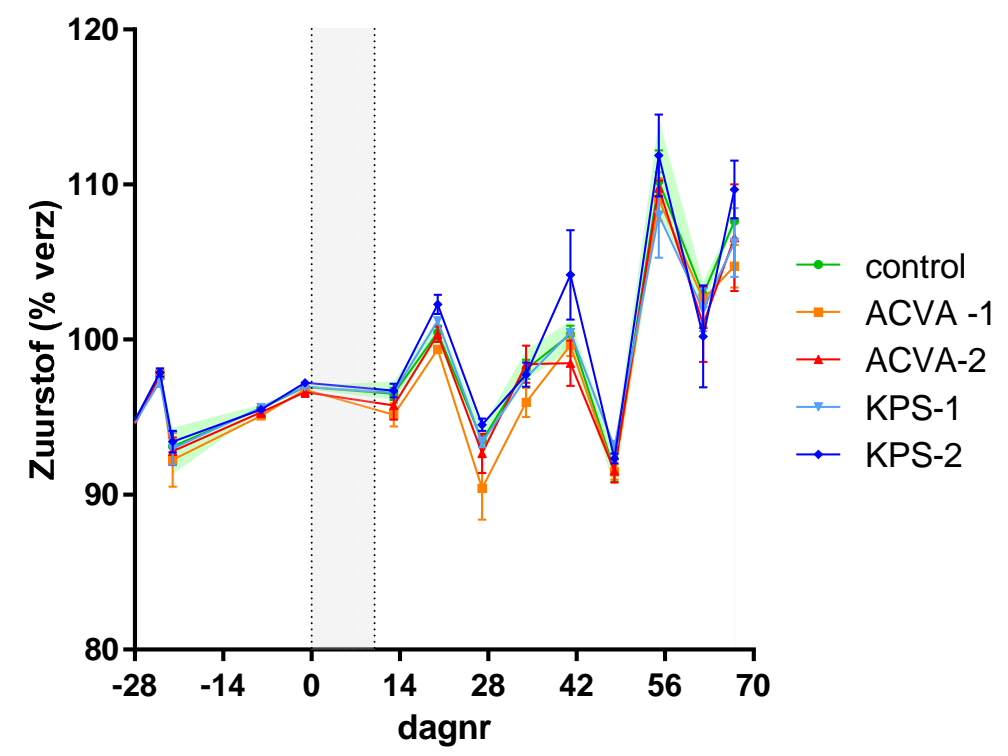

Figuur 6 Zuurstofgehalte in het mesocosm water met verschillende behandelingen. Voor elke behandeling zijn de gemiddelden en de range van de waarnemingen van de drie replica's weergegeven. De range van de controle mesocosms is weergegeven als groen veld rond de lijn die de gemiddelde aarde aangeeft. De kolom geeft de doseringsperiode tussen dag 0 en 10 weer. 


\subsection{4 $\mathrm{pH}$}

De zuurgraad $(\mathrm{pH})$ van het Oosterschelde water waarmee de mesocosm gevuld werden was 8.5. Dit veranderde nauwelijks tot dag 14 , waarna in alle mesocosms een geleidelijke stijging van de $\mathrm{pH}$ zichtbaar werd (Figuur 7). Deze stijging versnelde na dag 35, waarschijnlijk onder invloed van toenemende primaire productie. Rond dag 56 werd een $\mathrm{pH}$-waarde van 9 overschreden. De maximale $\mathrm{pH}$ waarde lag rond 9.2 en is gemeten op de laatste bemonsteringsdag van de studie.

Hoewel de ontwikkeling van de $\mathrm{pH}$ in alle mesocosms hetzelfde patroon volgt lijkt de stijging iets minder snel te verlopen in de KPS-1 mesocosms. De verschillen tussen de mesocosms blijven gering, maar op dag 62 is de pH in de KPS-1 mesocosms eenmalig significant lager dan in de controle mesocosms.

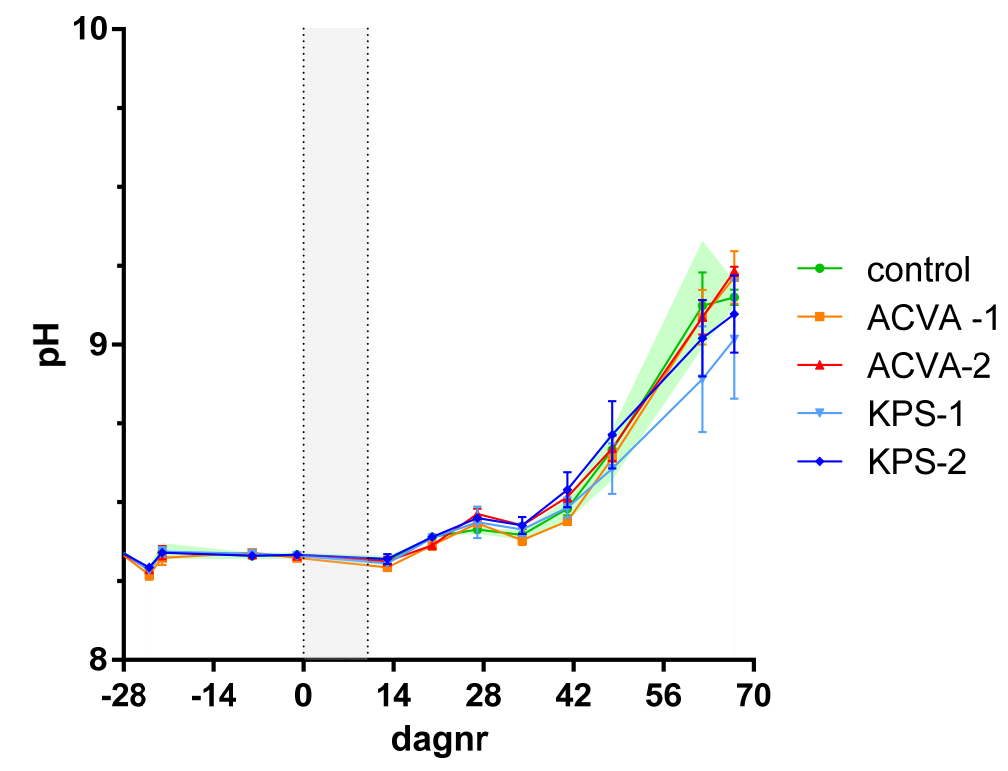

Figuur 7 Zuurgraad $(\mathrm{pH})$ van het mesocosm water met verschillende behandelingen. Voor elke behandeling zijn de gemiddelden en de range van de waarnemingen van de drie replica's weergegeven. De range van de controle mesocosms is weergegeven als groen veld rond de lijn die de gemiddelde aarde aangeeft. De kolom geeft de doseringsperiode tussen dag 0 en 10 weer. 


\subsubsection{Troebelheid}

De nanodeeltjes suspensie die in de mesocosms werd gedoseerd had een melkachtig uiterlijk en veroorzaakte een vertroebeling van het water. In de laag gedoseerde mesocosms was deze vertroebeling al snel niet meer waarneembaar. In de mesocosms met de hoge doseringen bleef het water gedurende enkele dagen na de laatste dosering enigszins troebel.

De troebelheidsmetingen bevestigen deze waarnemingen (Figuur 8). Gedurende de gehele studie schommelt de troebelheid van het water in de mesocosms rond $1 \mathrm{NTU}$, wat duidt op helder water. Alleen tijdens en vlak na de doseringsperiode worden hogere NTU waarden (troebeler water) gemeten, met name in de hoog gedoseerde mesocosms. In de ACVA-1 en KPS-1 mesocosms is slechts een geringe -niet statistisch significante- vertroebeling geregistreerd. De dosering van de AKVA-deeltjes lijkt een iets hogere troebelheid te veroorzaken dan de KPS-deeltjes, maar beide behandelingen leiden tot 13 dagen na de aanvang van de dosering tot significant hogere troebelheid dan in de controle mesocosms.

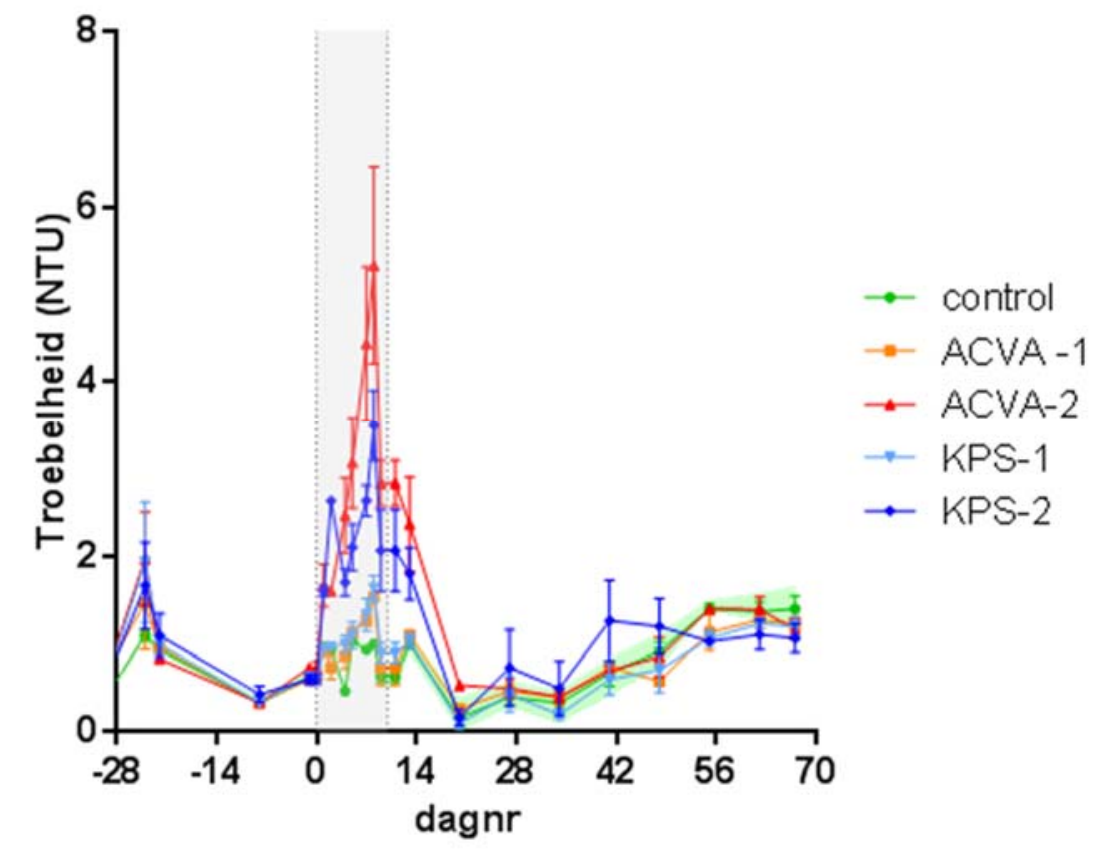

Figuur 8 Troebelheid (turbiditeit) van het mesocosm water met verschillende behandelingen. Voor elke behandeling zijn de gemiddelden en de range van de waarnemingen van de drie replica's weergegeven. De range van de controle mesocosms is weergegeven als groen veld rond de lijn die de gemiddelde aarde aangeeft. De kolom geeft de doseringsperiode tussen dag 0 en 10 weer.

\subsubsection{Nutriënten}

De gehalten anorganisch stickstof en ortho-fosfaat in de waterkolom van de mesocosms waren gedurende de gehele studie relatief laag. In de loop van de studie vindt in alle mesocosms een lichte stijging plaats, maar ook aan het eind van de studie zijn de gehalten laag. De gehalten zijn overeenkomstig de waarden die in het voorjaar gevonden worden in de Oosterschelde (Foekema et al. 2016).

Het silicaat gehalte is aanvankelijk relatief hoog, waarschijnlijk als gevolg van uitloging uit het sediment. Op dag 34 is het gehalte in alle mesocosms gedaald tot beneden de detectielimiet. Ook bij de laatste bemonstering liggen de silicaat gehalten nauwelijks hoger. 

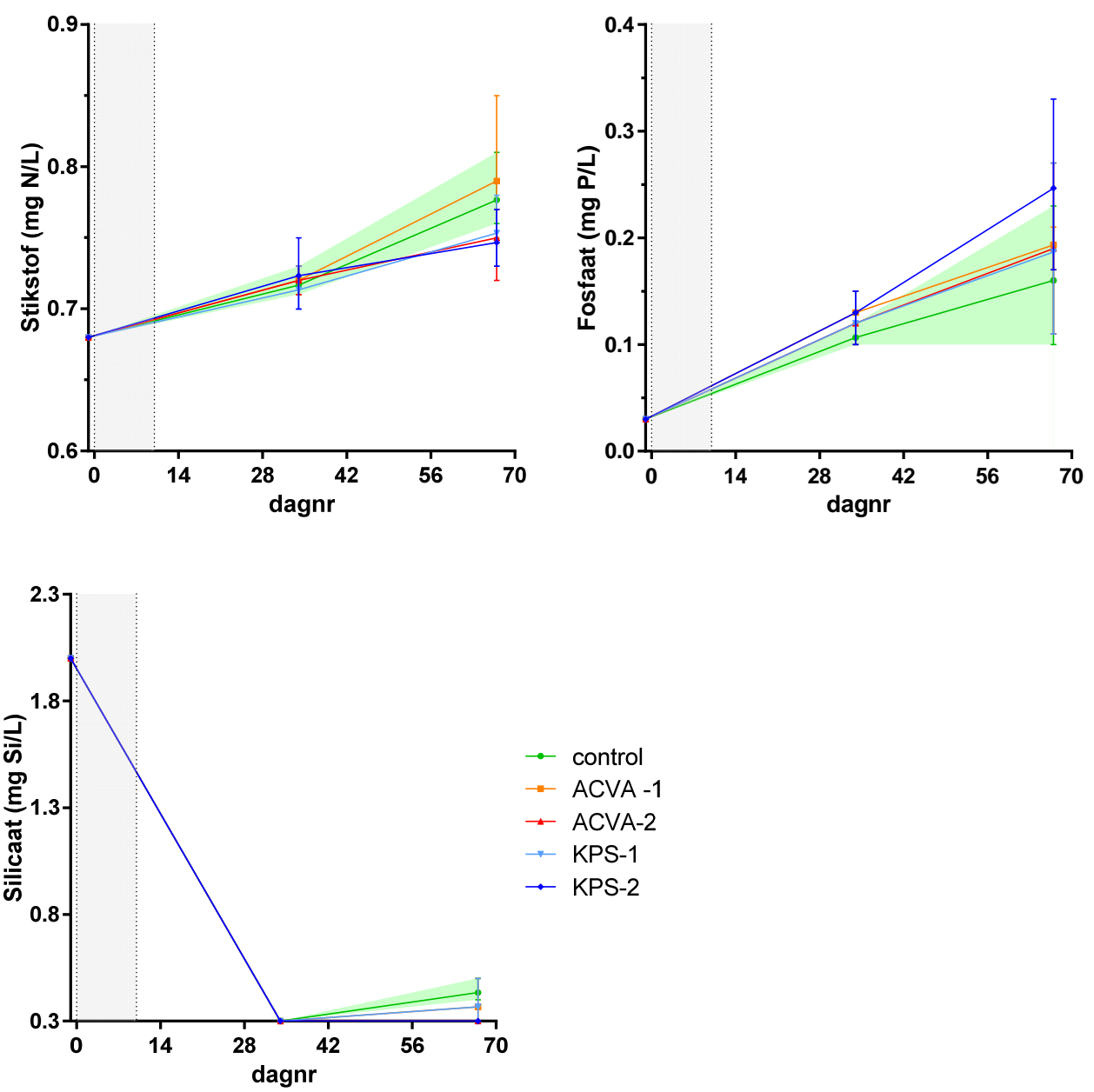

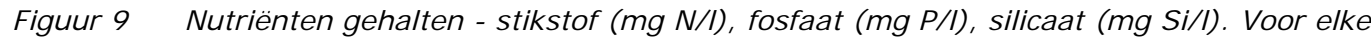
behandeling zijn de gemiddelden en de range van de waarnemingen van de drie replica's weergegeven. De range van de controle mesocosms is weergegeven als groen veld rond de lijn die de gemiddelde aarde aangeeft. De kolom geeft de doseringsperiode tussen dag 0 en 10 weer. 


\subsection{Biologische resultaten}

\subsubsection{Phytoplankton}

Het chlorofyl-a gehalte van het water is een maat voor de fytoplankton biomassa. In grote lijnen ontwikkelde de chlorofylgehalten zich in de controles en de behandelingen op gelijke wijze. Na een rustige opbouw gedurende de acclimatisatieperiode ontwikkelt zich tussen dag 0 en 28 een lage piek tot maximaal $7 \mu \mathrm{g}$ chlorofyl/L. Na dag 48 start een tweede piek die duurt tot het eind van de studie. Hierbij worden hogere chlorofylgehalten bereikt. Tijdens deze tweede piek neemt de variatie tussen de mesocosms toe.

Groenalgen en diatomeeën vormden de belangrijkste fytoplankton groepen, waarbij de groenalgen het meest dominant waren (Figuur 10). Gedurende de eerste 5 weken na aanvang van de dosering laten de diatomeeën en de groenalgen een gelijke ontwikkeling zien. Voor beide fytoplanktongroepen lijkt de chlorofylpiek na de doseringsperiode enkele dagen langer stand te houden in de hoge behandelingen (ACVA-2 en KPS-2) dan in de andere mesocosms, maar dit leidt niet tot statistisch significante verschillen.

Met uitzondering van een eenmalig significant lager gehalte groenalgen chlorofyl in de KPS-2 mesocosms op dag 62, waren er geen statistische significante verschillen tussen de chlorofyl gehalten in de controles en de behandelingen.
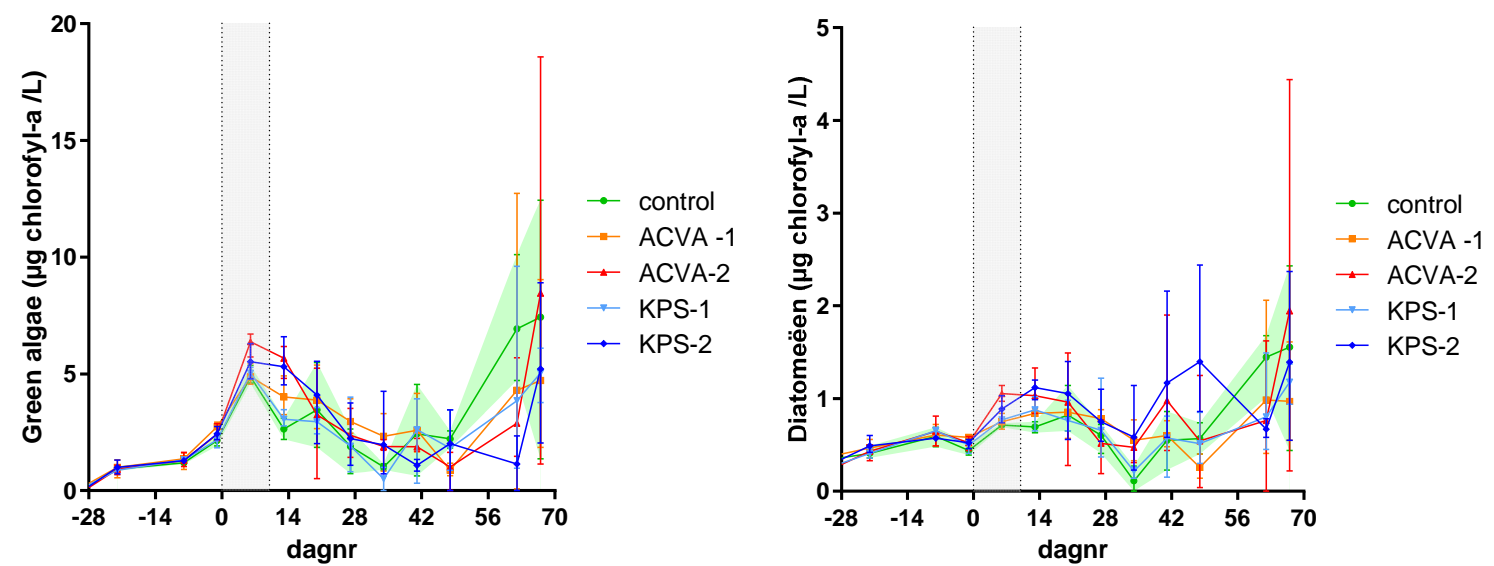

Figuur 10 Dichtheden van groenalgen (links) diatomeeën (rechts) uitgedrukt als chlorofyl-a gehalte in de waterkolom van de mesocosms met verschillende behandelingen. Voor elke behandeling zijn de gemiddelden en de range van de waarnemingen van de drie replica's weergegeven. De range van de controle mesocosms is weergegeven als groen veld rond de lijn die de gemiddelde aarde aangeeft. De kolom geeft de doseringsperiode tussen dag 0 en 10 weer. 


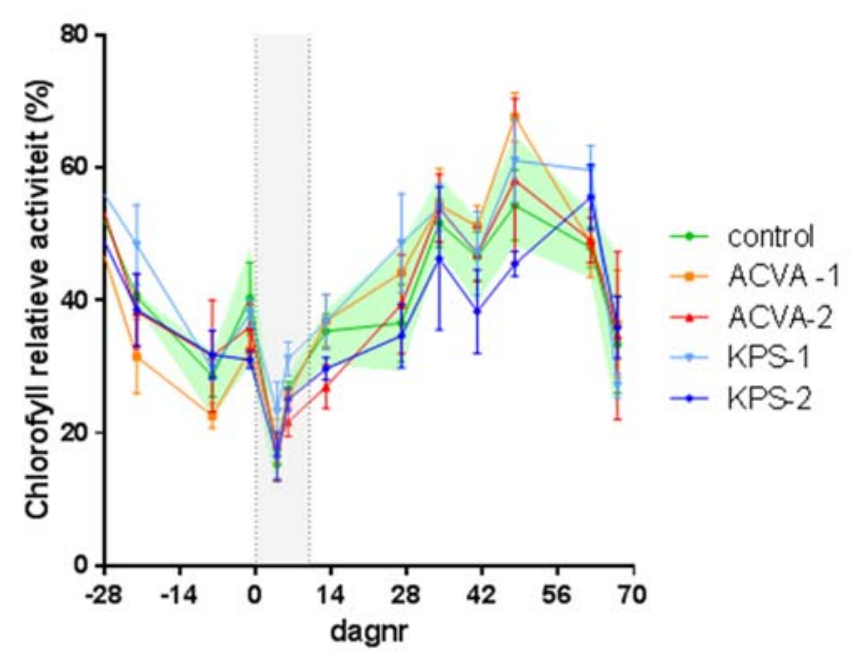

Figuur 11 Chlorofyl-a relatieve activiteit (\%) in het mesocosmwater met verschillende behandelingen. Voor elke behandeling zijn de gemiddelden en de range van de waarnemingen van de drie replica's weergegeven. De range van de controle mesocosms is weergegeven als groen veld rond de lijn die de gemiddelde aarde aangeeft. De kolom geeft de doseringsperiode tussen dag 0 en 10 weer.

De activiteit van het chlorofyl is indicatief voor de vitaliteit van de fytoplankton gemeenschap. Ook voor deze parameter volgen alle mesocosms in grote lijnen hetzelfde patroon, zonder significante verschillen tussen controles en behandelde mesocosms. Tijdens de acclimatisatie periode daalt de activiteit aanvankelijk van rond 50 naar ca 40\%, maar in de laatste week voor de dosering neemt de activiteit weer toe. Vanaf het moment dat de dosering start vindt in alle mesocosm een scherpe daling van de activiteit plaats. De laagste waarden worden gemeten op dag 4 tijdens de doseringsperiode. Deze dip is aanwezig in alle mesocosms inclusief de controles en is van korte duur. Vanaf dag 6 stijgt de activiteit weer snel tot dat rond dag 48 de hoogste waarden worden bereikt. Op het moment dat de laatste analyses worden uitgevoerd is de activiteit in alle mesocosms gedaald.

\subsubsection{Zooplankton}

De zooplankton gemeenschap in de mesocosms bestond uit verschillende soorten copepoden, rotiferen en de larven van bivalven, gastropoden, zeepokken en polychaete wormen. De totale dichtheden varieerden tussen ca 50 en 200 individuen per liter. De hoogste dichtheden werden aangetroffen in de monsters van dag 13 en dag 67. Op deze dagen waren ook de verschillen tussen de mesocosms inclusief de replica's, het grootst. Er zijn geen aanwijzingen dat de totale dichtheden systematisch door de behandelingen zijn beïnvloed.

Bij aanvang van de doseringsperiode bestond de zoöplanktongemeenschap in de mesocosms uit 9 tot 13 te onderscheiden taxonomische groepen/soorten. Op dag 13 bleek dit aantal licht te zijn gestegen naar 10 tot 17 per mesocosm. Bij de volgende bemonsteringen werden lagere aantallen gevonden en tijdens de laatste bemonstering bevatten de mesocosms tussen de 6 en 12 zoöplanktonsoorten. Deze ontwikkeling was vergelijkbaar in alle mesocosms. 

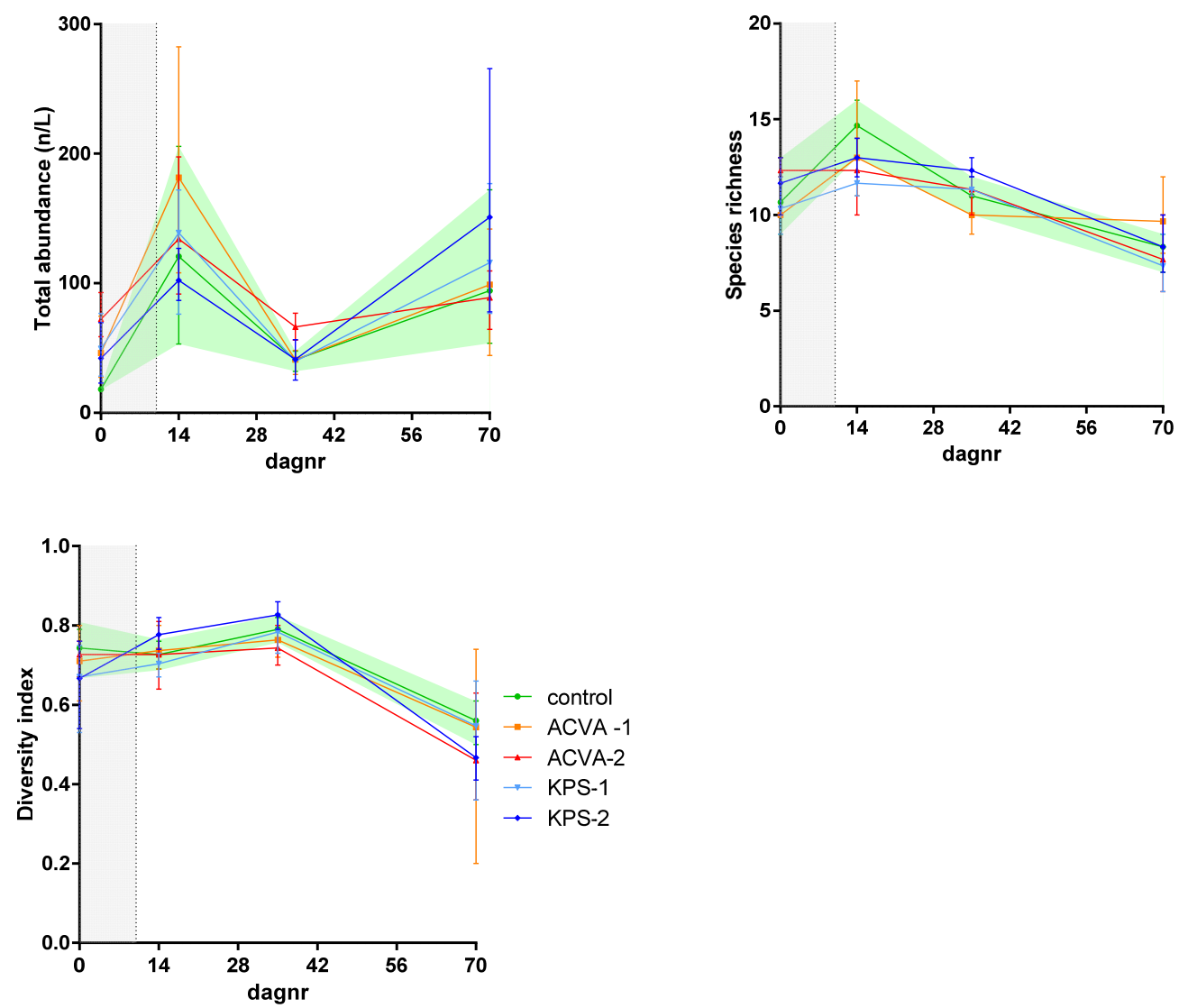

Figuur 12 Zooplankton gemeenschap in de mesocosms: Totale abundantie, soorten rijkdom (species richness) en diversiteit (Simpson's biodiversity index). Voor elke behandeling zijn de gemiddelden en de range van de waarnemingen van de drie replica's weergegeven. De range van de controle mesocosms is weergegeven als groen veld rond de lijn die de gemiddelde aarde aangeeft. De kolom geeft de doseringsperiode tussen dag 0 en 10 weer.

Acartia sp, Eurytemora sp. en Pseudodiaptomus sp. waren de meest dominante copepode groepen. Van Acartia sp. werden de hoogste dichtheden gevonden op dag 14. Dit was het geval voor alle mesocosms, zonder indicaties van een effect van de dosering die 4 dagen eerder was beëindigd. Hierna liepen de aantallen terug tot praktisch nul op dag 67.

De ontwikkeling van de aantallen Eurytemora sp. verliep in de met nanodeeltjes behandelde mesocosms volgens hetzelfde patroon als de hierboven beschreven ontwikkeling van Acartia sp. In de controle mesocosm leek de ontwikkeling in de replica's echter uit de pas te lopen. Doordat op dag 14 de aantallen in een van de replica's piekten en op dag 35 in een andere, waren de gemiddelde aantallen in de controle mesocosms ook op dag 35 nog hoog. Dit verschil is niet significant. 

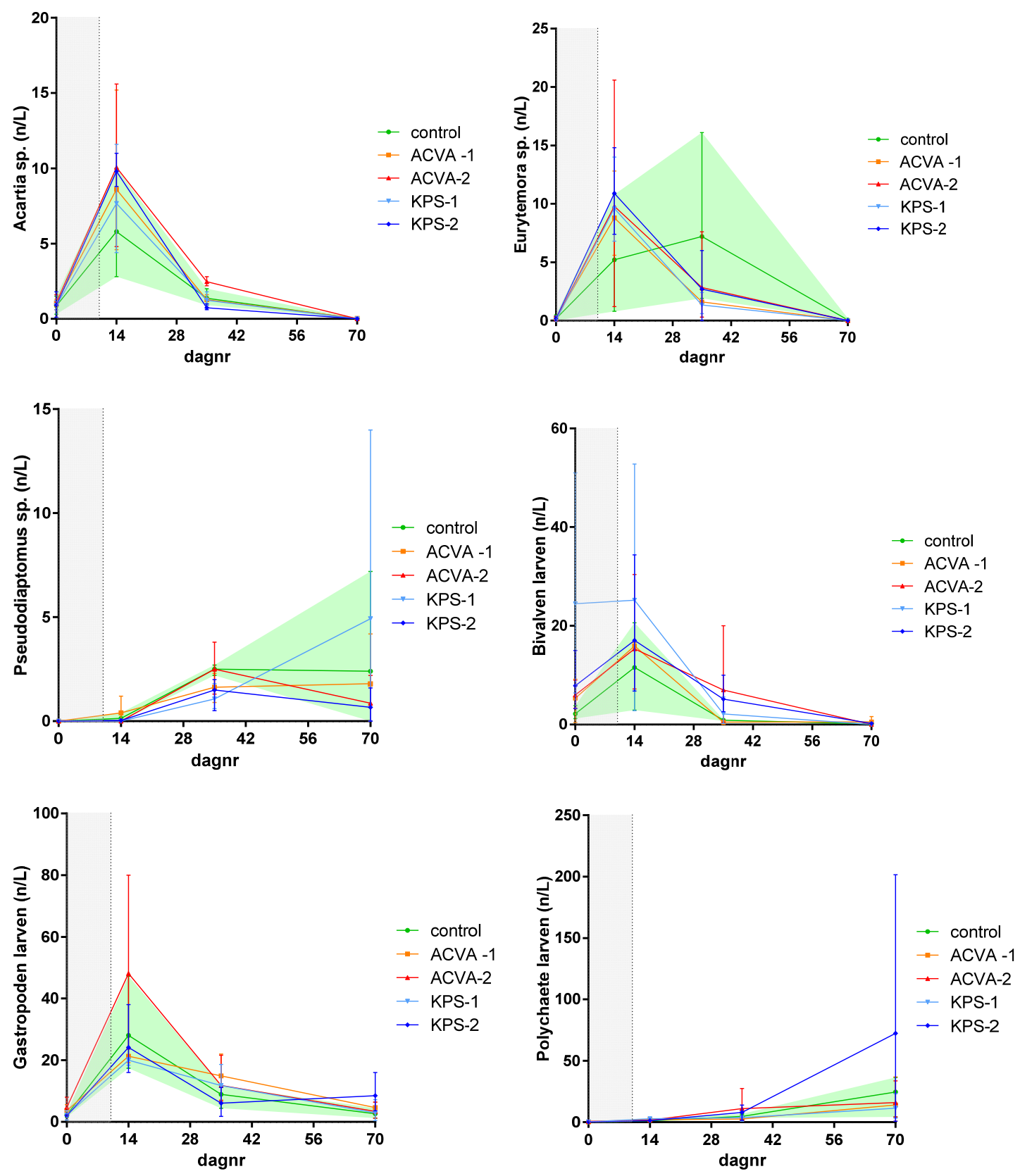

Figuur 13 Dichtheden van Acartia sp., Eurytemora sp., Pseudodiaptomus sp., bivalve larven, gastropoda larven en polygaeten larven $(n / l)$ in mesocosms met verschillende behandelingen. Voor elke behandeling zijn de gemiddelden en de range van de waarnemingen van de drie replica's weergegeven. De range van de controle mesocosms is weergegeven als groen veld rond de lijn die de gemiddelde aarde aangeeft. De kolom geeft de doseringsperiode tussen dag 0 en 10 weer.

Naast de copepoden, bestond een belangrijk deel van het zoöplankton uit de pelagische larven van schelpdieren en wormen. Omdat de eerste zoöplanktonmonsters verzameld werden 6 weken na de introductie van het Oosterschelde water en de meeste soorten een korter pelagisch larvaal stadium kennen zal het merendeel van deze larven afkomstig zijn van die dieren in de mesocosms. De schelpdierlarven die in de meeste mesocosms op dag 13 in de hoogste aantallen aanwezig waren, zijn hoogstwaarschijnlijk nakomelingen van de mosselen en de kokkels in de mesocosms. Door extreem hoge aantallen in één van de replica's liggen de gemiddelde aantallen in de KPS-1 mesocosms op dag 0 hoger dan de gemiddelden van de andere behandelingen. Door de hoge spreiding tussen de replica's is deze waarneming niet significant. Op dag 35 zijn de aantallen pelagische schelpdierlarven in de meeste mesocosms teruggelopen en tijdens de laatste bemonstering op dag 67 worden zij vrijwel niet meer aangetroffen. Er zijn geen indicaties dat de behandelingen de dichtheden van de schelpdierlarven hebben beïnvloed. 
De ontwikkeling van de aantallen gastropode (slakken) larven is vergelijkbaar met die van de larven van de schelpdieren; een piek rond dag 13 gevolgd door een geleidelijke afname. Ook hier zijn geen indicaties gevonden voor een relatie met de behandelingen.

Het aantal larven van Polychaete wormen is vrijwel nul in alle mesocosms op dag 0 wanneer de dosering start, en ontwikkelt zich gestaag tot gemiddeld 20 individuen per liter aan het eind van de studie voor de controles en de meeste behandelingen. Eén van de replica's van de KPS-2 mesocosms bevat op dag 67 echter substantieel hogere aantallen polychaete larven (202 ind./L). Hierdoor stijgt het gemiddelde voor deze behandeling zonder dat daar conclusies aan kunnen worden verbonden over de relatie met de behandeling.

\subsubsection{Alikruiken}

Omdat alikruiken in staat zijn uit de mesocosm te kruipen, worden van deze soort nooit alle ingezette dieren aan het eind van een studie teruggevonden. De overleving wordt daarom bepaald als het percentage levende alikruiken op het totaal in de mesocosms aangetroffen slakkenhuizen. In deze studie bedroeg die overleving over alle mesocosms 68 tot 90\% (77\% gemiddeld) zonder verschillen tussen behandelingen. De lengte van de alikruiken aan het eind van de studie was zeer gelijkmatig in alle mesocosms met een gemiddelde lengte van $16.3 \mathrm{~mm}$ en een range van 15.6-16.8 mm. De individuele drooggewichten en de daarvan afgeleide conditie-index liet minimale verschillen zien tussen behandelingen (Figuur 14). De verschillen tussen de behandelingen waren niet significant.
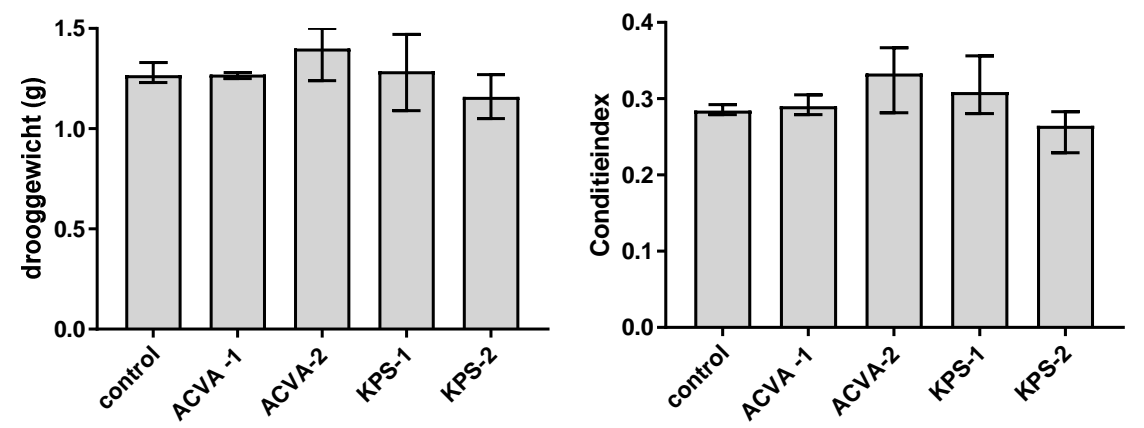

Figuur 14 Drooggewicht ( $\mathrm{g}$ ) en conditieindex op basis van drooggewicht voor alikruiken (Littorina litorea) in mesocosms met verschillende behandelingen.

\subsubsection{Mosselen}

Het percentage van de ingezette mosselen dat de studie overleeft neemt in de loop van de studie iets af in alle behandelingen, inclusief de controles. Tussen dag 34 en 76 vindt er iets meer sterfte plaats in de KPS-2 mesocosms wat op dag 67 leidt tot een significant lagere overleving ten opzichte van de controles (85 vs 93\%; Figuur 15).

Het gewicht van de overlevende mosselen inclusief schelp neemt tussen dag 14 en 67 in controle toe van 1.5 naar 1.8 gram en wijkt niet af van de mesocosms waaraan nanodeeltjes zijn gedoseerd.

(Figuur 15). Omdat de mosselen voor eventueel histopathologisch onderzoek zijn bewaard kon geen vleesgewicht worden bepaald. Hierdoor was het ook niet mogelijk een betrouwbar conditie index te berekenen. 

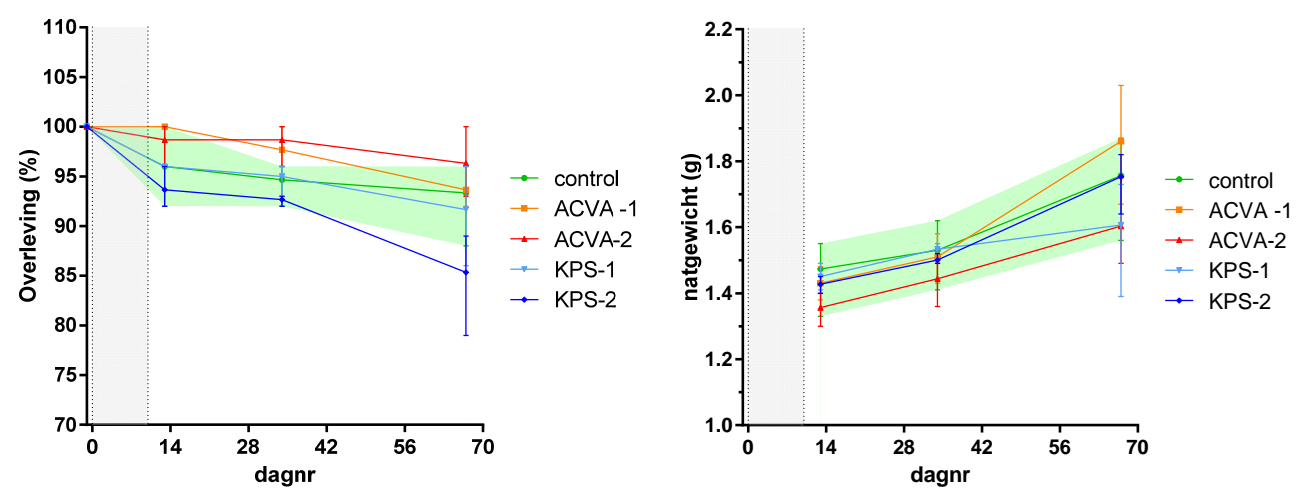

Figuur 15 Overleving (\% van het totaal geïntroduceerde hoeveelheid), en ontwikkeling van het gewicht (g natgewicht inclusief schelp) mosselen in mesocosms met verschillende behandelingen. Voor elke behandeling zijn de gemiddelden en de range van de waarnemingen van de drie replica's weergegeven. De range van de controle mesocosms is weergegeven als groen veld rond de lijn die de gemiddelde aarde aangeeft. De kolom geeft de doseringsperiode tussen dag 0 en 10 weer.

De groei van mossel is ook waarneembaar in schelplengte die over alle mesocosms gemeten toeneemt van gemiddeld $23.6 \pm 0.5$ naar $25.1 \pm 0.5 \mathrm{~mm}$. Wanneer de schelpgroei per behandeling wordt beschouwd (Figuur 16), lijkt deze iets sterker te zijn in de ACVA mesocosms. De verschillen tussen de behandelingen en controle zijn echter niet statistische significant.

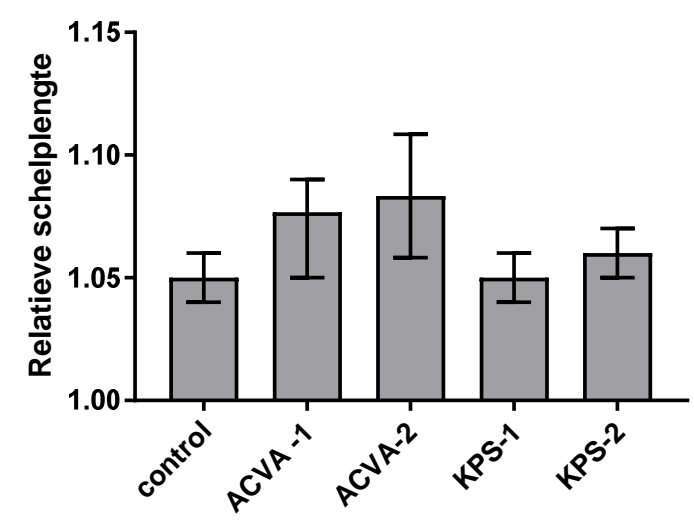

Figuur 16 Fractie van de schelplengte van de mosselen bij introductie in de mesocosms en de laatste bemonstering.

\subsubsection{Kokkels}

Van de uitgezette kokkels overleefde gemiddeld $88 \%$ de duur van de studie (Figuur 17). De verschillen tussen de behandelingen zijn niet significant.

Gedurende de studie groeien de kokkels in alle mesocosms van gemiddeld $14 \mathrm{~mm}$ tot een gemiddelde schelplengte tussen 21 en $24 \mathrm{~mm}$, zonder indicaties dat er een effect is van de behandeling.

Logischerwijs neemt ook het vleesgewicht van de kokkels toe. Dit gebeurt echter niet evenredig in alle behandelingen. De kokkels uit de KPS 1 en KPS 2 mesocosms hebben een significant lager drooggewicht aan het einde van de studie dan de kokkels uit de controle mesocosms. Onderling verschillen beide behandelingen echter niet.

De conditie van de kokkels bij aanvang van de studie was relatief laag, en nam toe tijdens het verblijf in de mesocosms. De conditie index laat eenzelfde trend zien als het drooggewicht. Deze verschillen zijn echter niet statistische significant. 

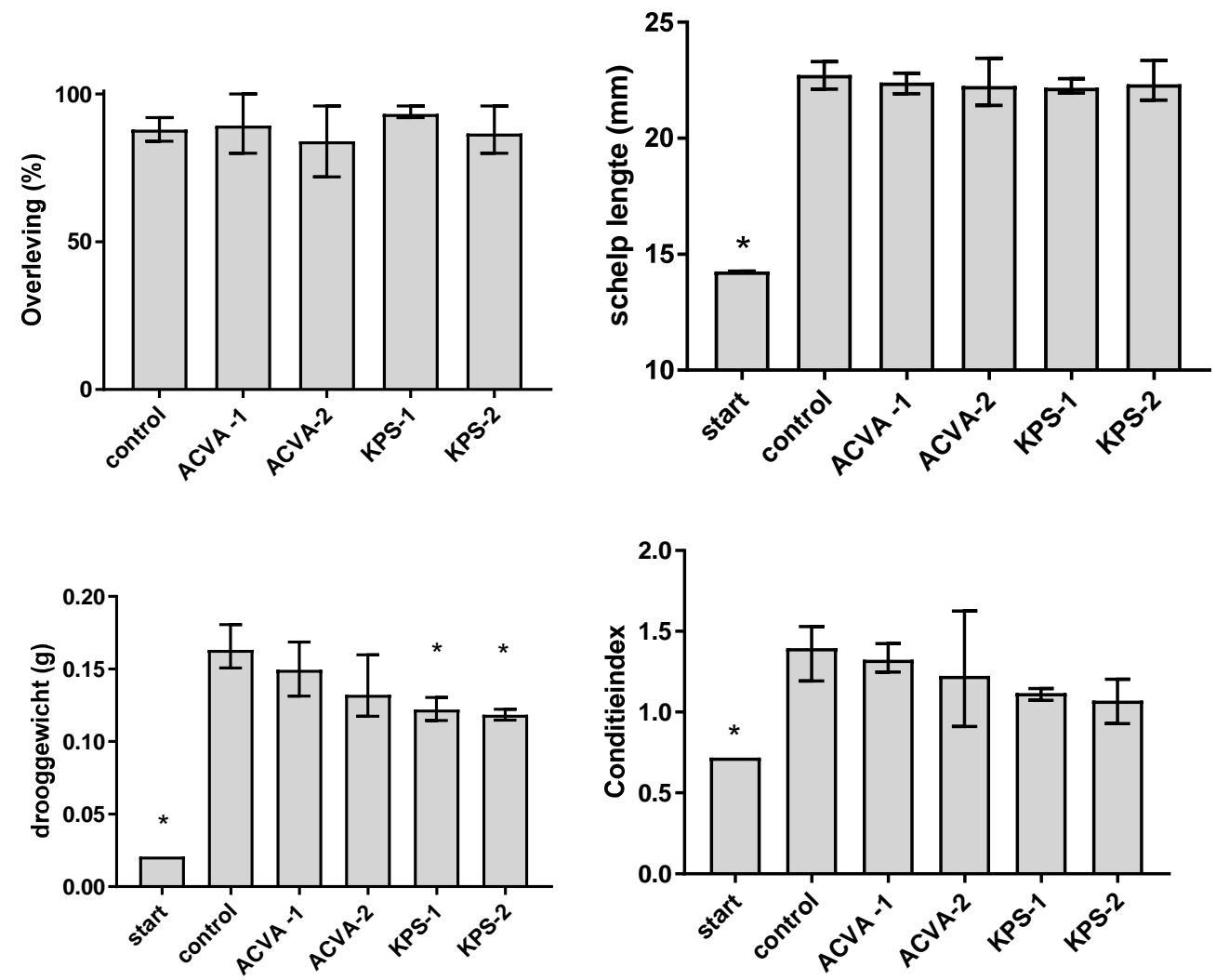

Figuur 17 Overleving, schelplengte, vleesgewicht en conditie index van de kokkels bij aanvang (start) en beëindiging van de studie. Waarden die significant afwijken van de controle mesocosms zijn weergegeven met '*'

\subsubsection{Sponzen}

Het gemiddelde gewicht van de geïntroduceerde sponzen aan het eind van de studie was $37 \pm 12 \mathrm{~g}$ natgewicht. Op dag 35 bleek één van de spons enclosures in een KPS-1 mesocosm te zijn overwoekerd door de kolonievormende zakpijp Botrylloides leachi (Figuur 19). Deze spons is uit de studie verwijderd. De zakpijp werd daarna in niet meer aangetroffen in deze of andere mesocosms.

Het relatieve gewicht van de sponzen in de mesocosms (Figuur 18) nam aanvankelijk iets af. Rond dag 14 werden in alle mesocosms de laagste spons gewichten gemeten. Tijdens de bemonstering op dag 34 bleken de gewichten van de sponsen in alle mesocosms (iets) hoger te zijn dan het uitgangsgewicht. In het resterende deel van de studie verloren alle sponsen enig gewicht. Op de laatste bemonsteringsdag was het relatieve gewicht gelijk aan het gewicht op dag 0 . De ontwikkeling van de biomassa van de sponzen gedurende de studie volgde hetzelfde patroon in alle mesocosms zonder indicaties te worden beïnvloed door de verschillende behandelingen (Figuur 18). 


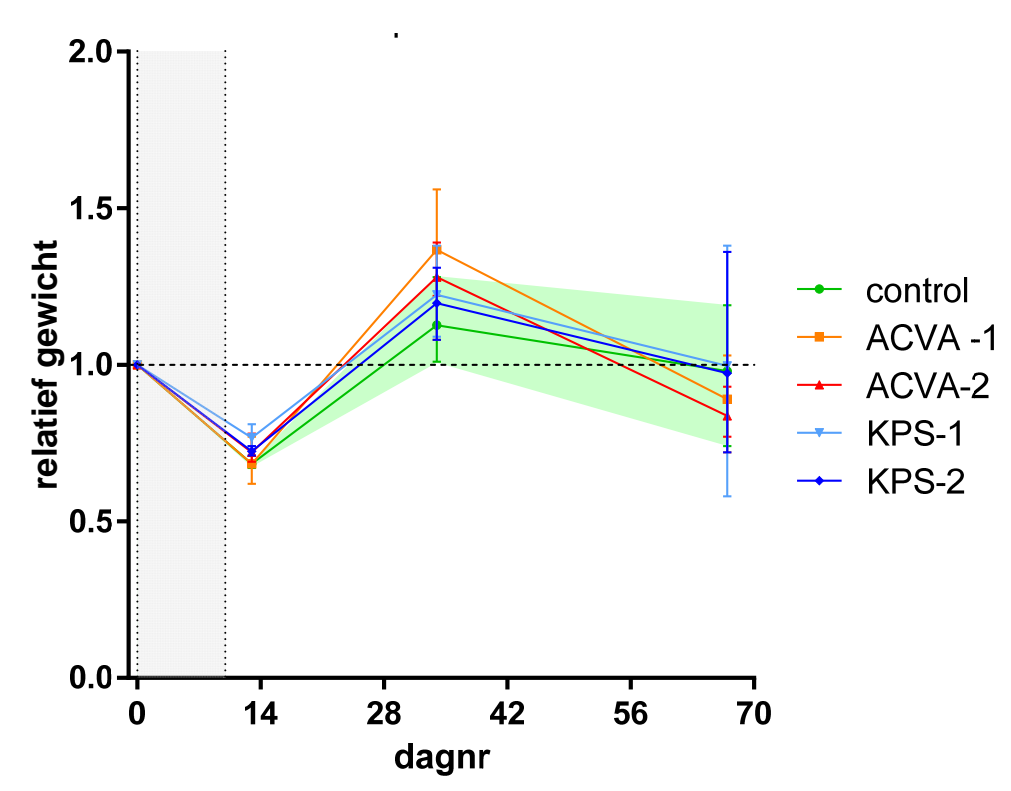

Figuur 18 Verloop van het gewicht van de op dag 0 in de mesocosms geïntroduceerde sponzen. Voor elke behandeling zijn de gemiddelden en de range van de waarnemingen van de drie replica's weergegeven. De range van de controle mesocosms is weergegeven als groen veld rond de lijn die de gemiddelde aarde aangeeft. De kolom geeft de doseringsperiode tussen dag 0 en 10 weer.

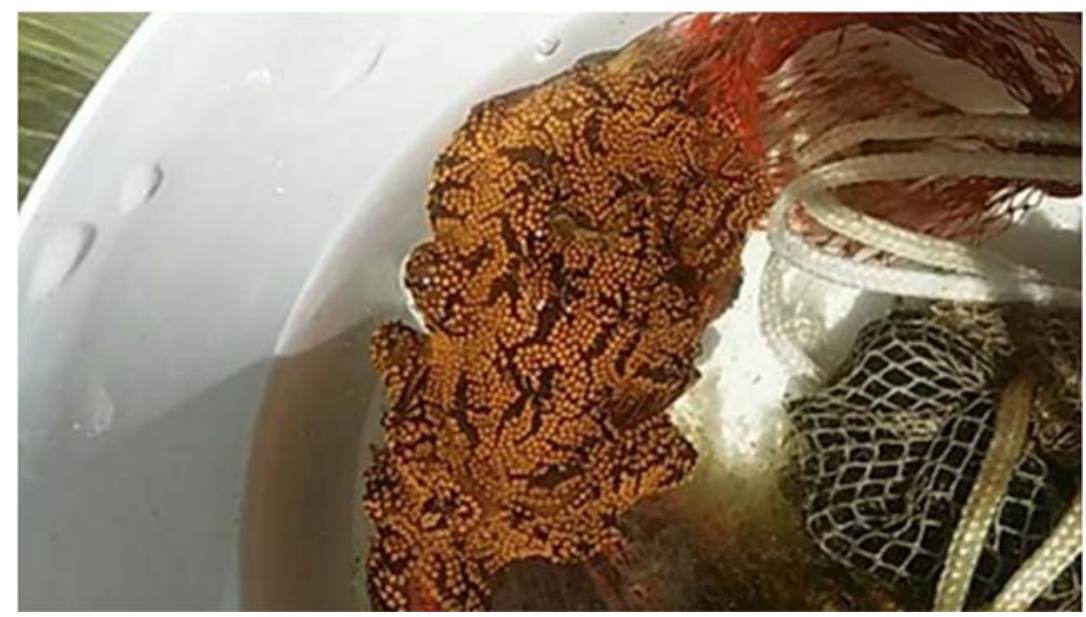

Figuur 19 Op dag 35 bleek de enclosure van één van de sponzen in mesocosm M8 (KPS-1) te zijn overwoekerd door de kolonievormende zakpijp Botrylloides leachi. Deze spons is uit de studie verwijderd.

\subsubsection{Zeepieren}

De overleving van de geïntroduceerde zeepieren over alle mesocosms was gemiddeld $77 \%(65-90 \%)$. De verschillen tussen de behandelingen waren niet significant. Bij introductie bedroeg het gemiddelde

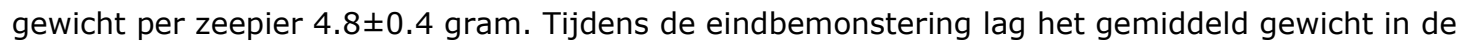
meeste mesocosms nog steeds rond deze waarde. De zeepieren uit de ACVA 1 en ACVA 2 mesocosms bleken echter een statistisch significant gewichtsverlies te hebben geleden tijdens de studie. Voor behandeling ACVA-1 bedroeg dit verschil tussen het gemiddelde individuele lichaamsgewicht bij inzetten en bij eindbemonstering 10\%, voor ACVA-2 was dit 19\%. Door (geringe) verschillen tussen de mesocosms in de aanvangsgewichten van de zeepieren zijn de absolute eindgewichten van deze behandelingen niet statistisch significant verschillend van de controles. 

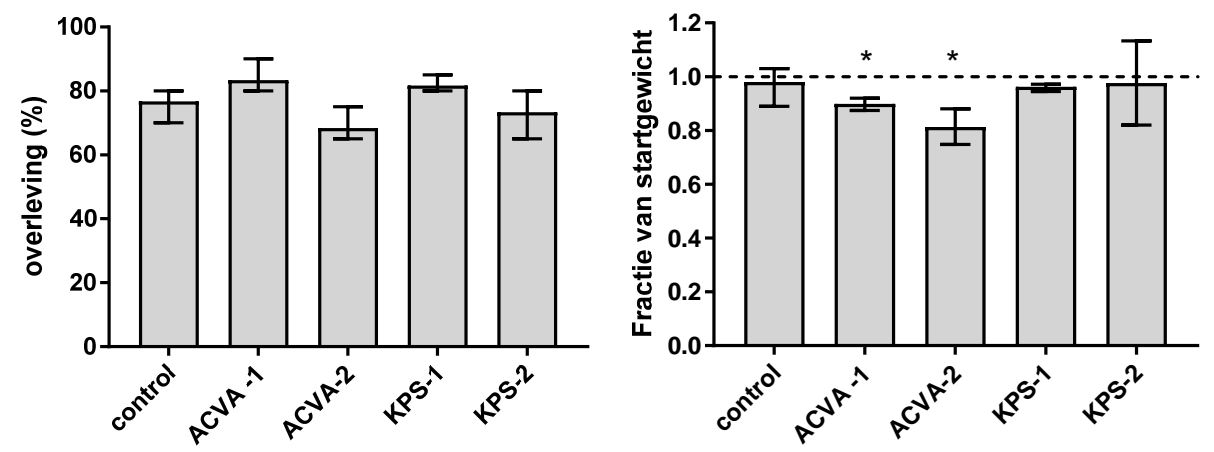

Figuur 20 Overleving (\%) en fractie van het totaal startgewicht van de geintroduceerde pieren in mesocosms met verschillende behandelingen. Waarden die significant afwijken van de controle mesocosms zijn weergegeven met ' $*$ '

\subsubsection{Benthosgemeenschap}

In de benthos monsters met een oppervlak van $706 \mathrm{~cm}^{2}$ die werden verzameld aan het eind van de studie werden tussen 400 en 1400 organismen aangetroffen. Vooral in behandeling KPS-2 bestond een grote spreiding tussen de replica's (Figuur 21). Er waren geen significante verschillen tussen de aantallen in de controle mesocosms en de behandelingen.

De monsters bevatten tussen 11 en 18 verschillende soorten en hoewel de soortenaantallen in de beide hoogste doseringen (ACVA-2 en KPS-2) gemiddeld lager zijn dan in de controles en de lage behandelingen zijn de verschillen niet statistisch significant.

De diversiteitsindex is het hoogst in de controle mesocosms, maar zonder significante verschillen met de behandelingen.
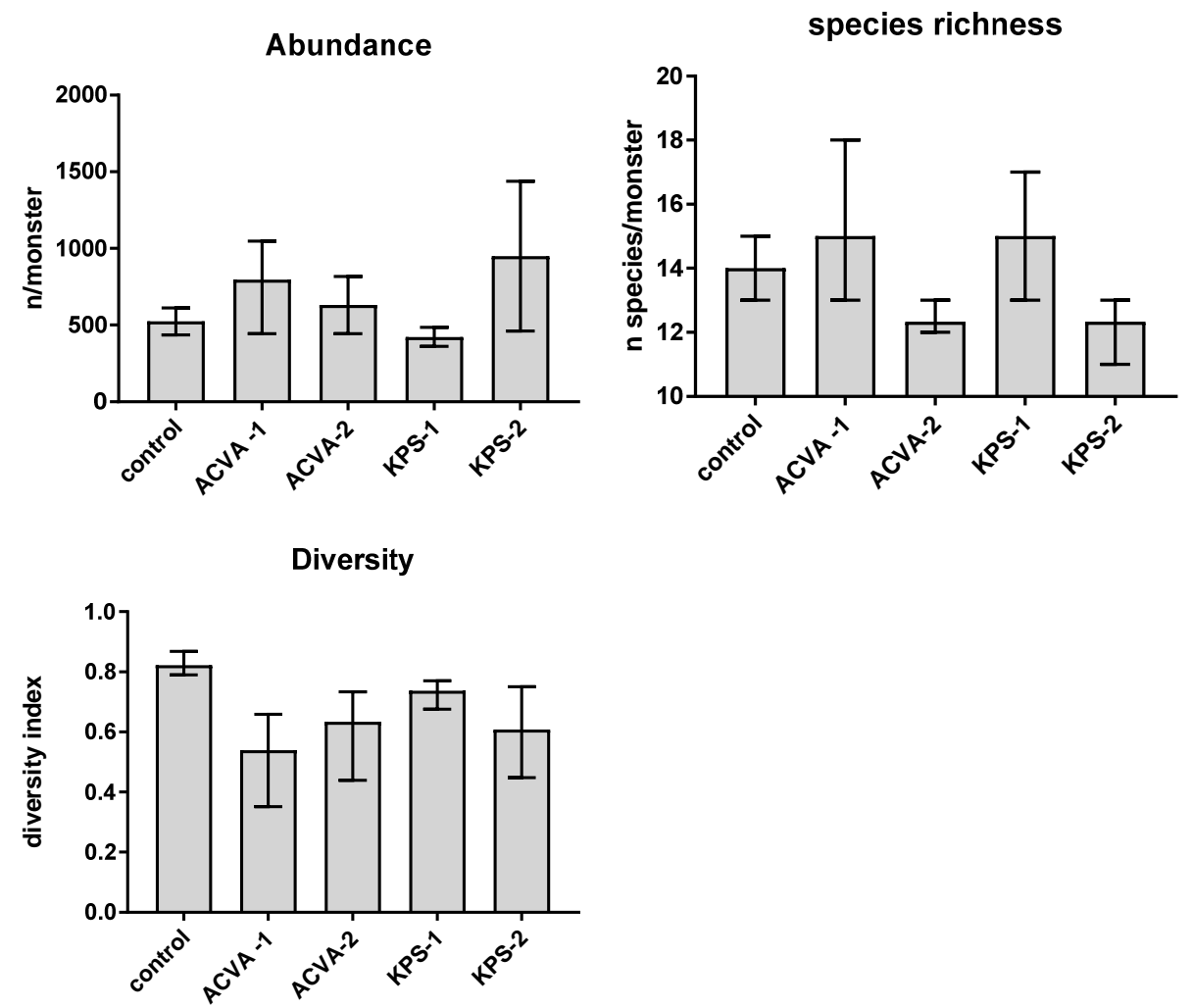

Figuur 21 Beschrijving van de benthosgemeenschap in totaal abundantie ( $\mathrm{n} / \mathrm{monster}$ ), soortenrijkdom (aantal soort/monster) en diversiteit in mesocosms met verschillende behandelingen. 

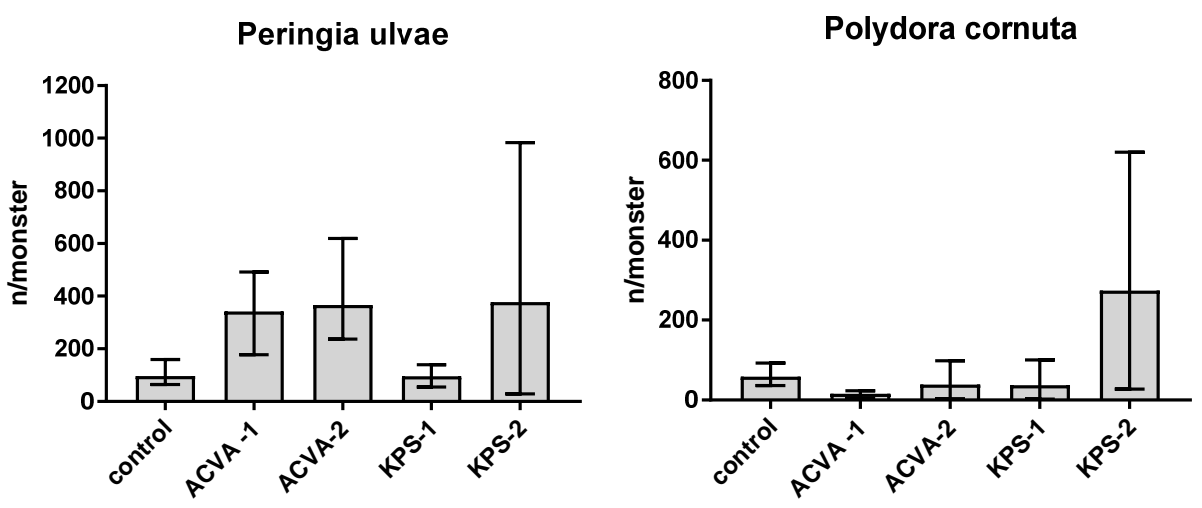

\section{Ctenodrilus serratus}

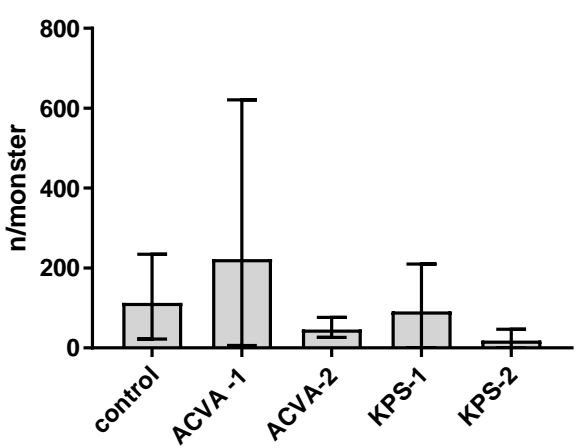

\section{Corophium volutator}

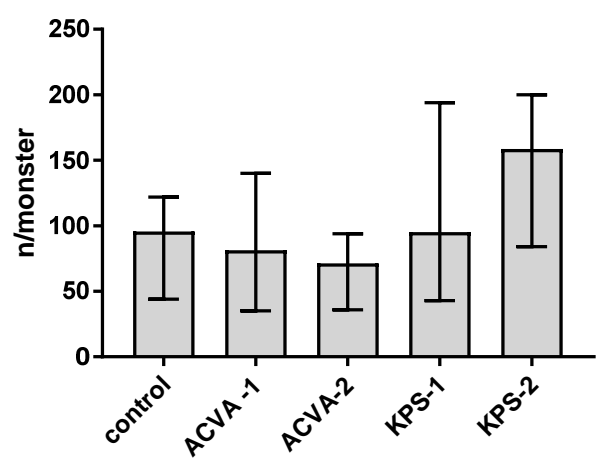

Figuur 22 Aantallen van de 4 meest dominante benthossoorten in de mesocosms per $706 \mathrm{~cm}^{3}$ (monsteroppervlak) in mesocosms met verschillende behandelingen.

De meest dominante vertegenwoordigers van de benthos gemeenschap waren het wadslakje Peringia ulvae, de wormen Polydora cornuta en Ctenodrilus serratus en het slijkgarnaaltje Corophium volutator. De dichtheden per behandeling zijn weergegeven in Figuur 22. Van deze en alle andere individuele soorten zijn geen significante verschillen tussen controles en met nanodeeltjes behandelde mesocosms gevonden. 


\subsection{Principal component analyse}

Voor dag 13 en dag 67 is met alle data die indicatief kunnen zijn voor een biologisch effect van de behandelingen (Tabel 6) een principal component analyse (PCA) uitgevoerd. De troebelheidsmetingen zijn in deze analyses niet meegenomen omdat deze direct door de behandeling worden beïnvloed en dus niet indicatief zijn voor een respons van het ecosysteem.

Tabel $6 \quad$ Meetdata die zijn gebruikt in de principal component analyse voor dag 13 en dag 67.

\begin{tabular}{|c|c|c|}
\hline & Dag 13 & Dag 67 \\
\hline Waterparameters & & \\
\hline Zuurstof concentratie & $\sqrt{ }$ & $\sqrt{ }$ \\
\hline $\mathrm{pH}$ & $\sqrt{ }$ & $\sqrt{ }$ \\
\hline Fosfaat concentratie & & $\sqrt{ }$ \\
\hline Stikstof concentratie & & $\sqrt{ }$ \\
\hline Silicaat concentratie & & $\sqrt{ }$ \\
\hline Fytoplankton & & \\
\hline Chlorofyll concentratie & $\sqrt{ }$ & $\sqrt{ }$ \\
\hline Chlorofyll activiteit & $\sqrt{ }$ & $\sqrt{ }$ \\
\hline Zooplankton & & \\
\hline total abundance zooplankton & $\sqrt{ }$ & $\sqrt{ }$ \\
\hline species richness zooplankton & $\sqrt{ }$ & $\sqrt{ }$ \\
\hline diversity index zooplankton & $\sqrt{ }$ & $\sqrt{ }$ \\
\hline Gastropod larven dichtheid & $\sqrt{ }$ & $\sqrt{ }$ \\
\hline Polychaete larven dichtheid & $\sqrt{ }$ & $\sqrt{ }$ \\
\hline Nauplii dichtheid & $\sqrt{ }$ & $\sqrt{ }$ \\
\hline Acartia sp. dichtheid & $\sqrt{ }$ & \\
\hline Eurytemora sp. dichtheid & $\sqrt{ }$ & \\
\hline Bivalve larven dichtheid & $\sqrt{ }$ & \\
\hline Macrofauna & & \\
\hline Spons relatieve biomassa & $\sqrt{ }$ & $\sqrt{ }$ \\
\hline Mossel overleving & $\sqrt{ }$ & $\sqrt{ }$ \\
\hline Mossel individueel gewicht & $\sqrt{ }$ & $\sqrt{ }$ \\
\hline Zeepier overleving & & $\sqrt{ }$ \\
\hline Zeepier relatief gewicht & & $\sqrt{ }$ \\
\hline Alikruik overleving & & $\sqrt{ }$ \\
\hline Alikruik individueel gewicht & & $\sqrt{ }$ \\
\hline total abundance benthos & & $\sqrt{ }$ \\
\hline species richness benthos & & $\sqrt{ }$ \\
\hline diversity index benthos & & $\sqrt{ }$ \\
\hline Peringia sp. dichtheid & & $\sqrt{ }$ \\
\hline Corophiidae sp. dichtheid & & $\sqrt{ }$ \\
\hline Polydora sp. dichtheid & & $\sqrt{ }$ \\
\hline Cerastoderma sp. dichtheid & & $\sqrt{ }$ \\
\hline Oligochaeta sp. dichtheid & & $\sqrt{ }$ \\
\hline Ctenodrilus sp. dichtheid & & $\sqrt{ }$ \\
\hline Gammarus sp. dichtheid & & $\sqrt{ }$ \\
\hline Isopoda dichtheid & & $\sqrt{ }$ \\
\hline Streblospio sp. dichtheid & & $\sqrt{ }$ \\
\hline
\end{tabular}


De PCA analyses lieten geen significante verschillen zien tussen de behandelingen (Figuur 23 en Figuur 24). In de PCA-plot voor dag 67 liggen evenwel twee van de 3 replica's van zowel de ACVA-2 als de KPS-2 behandelingen op enige afstand van de drie controles, maar in beide gevallen bevindt de derde replica zich in het 'controle gebied'.

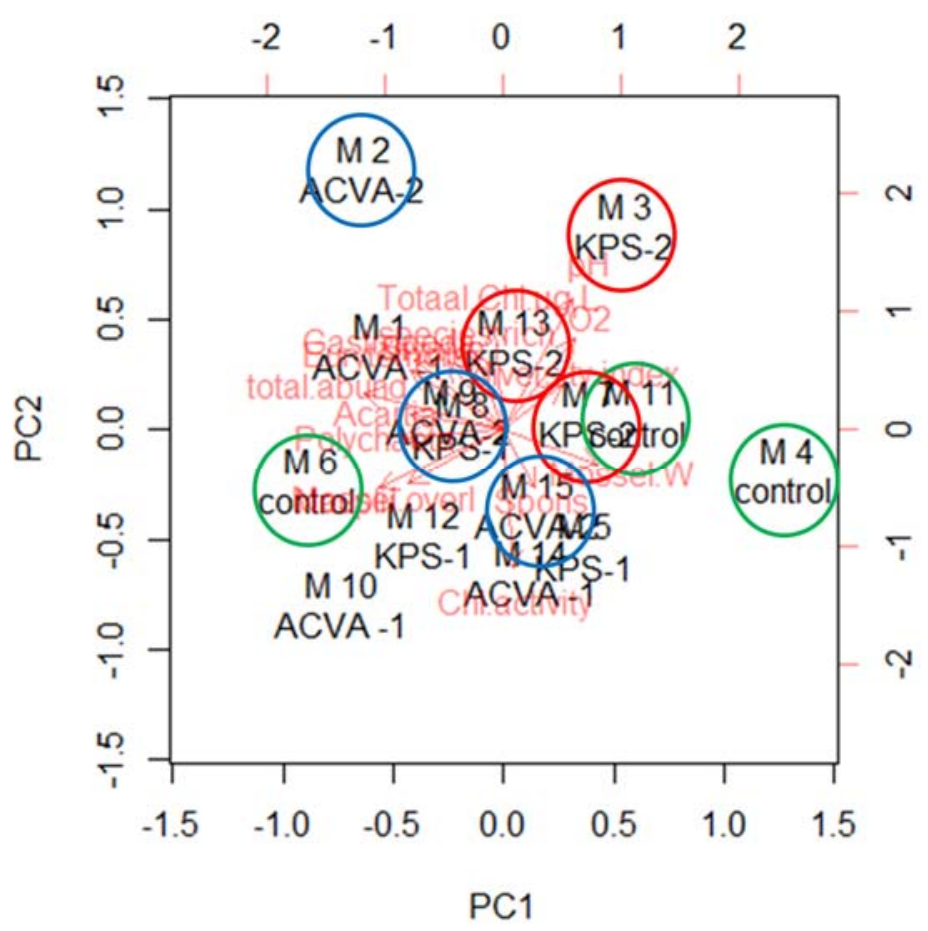

Figuur 23 PCA-plot voor dag 13. Ter indicatie zijn de controle mesocosms (groen) en de hoog gedoseerde mesocosms (KPS-2 Rood; ACVA-2 blauw) omcirkeld.

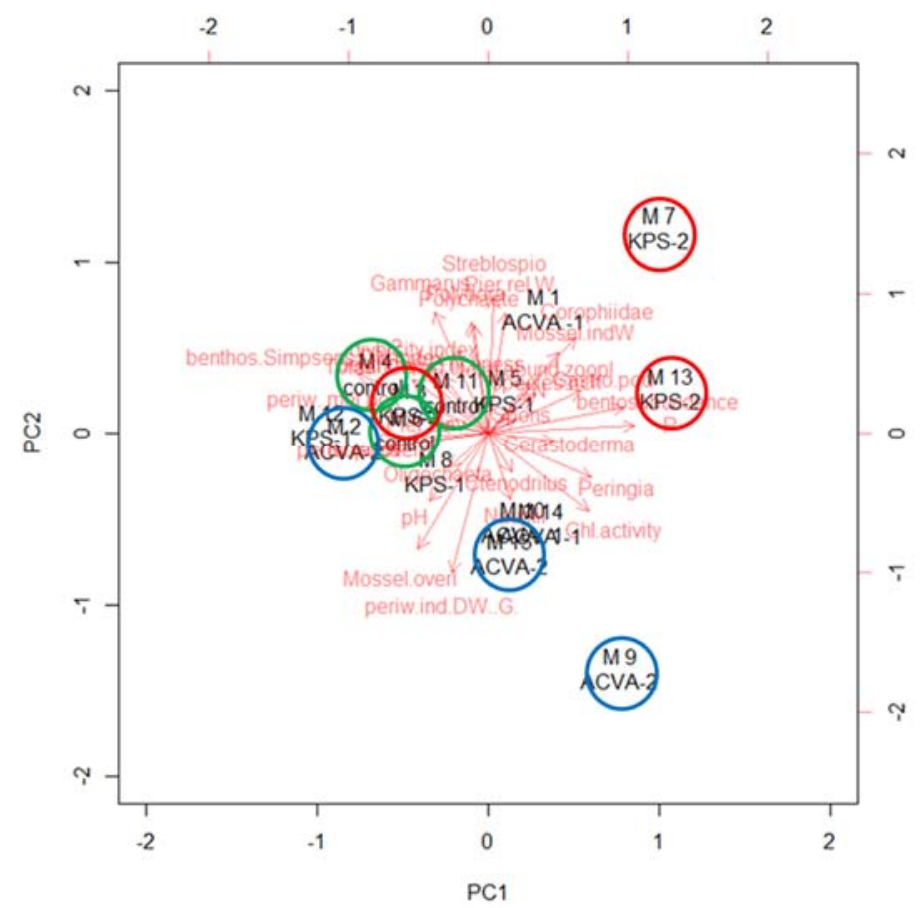

Figuur 24 PCA-plot voor dag 67. Ter indicatie zijn de controle mesocosms (groen) en de hoog gedoseerde mesocosms (KPS-2 Rood; ACVA-2 blauw) omcirkeld. 


\section{$4 \quad$ Discussie en conclusies}

De mesocosms die in deze studie als controle worden beschouwd, zijn door de dosering van de achtergrond hoeveelheid van de surfactant SDS geen controles in de ware zin van het woord. Idealiter zouden in een dergelijke studie ook volledig onbehandelde echte controle mesocosms aanwezig zijn. Door de onverwacht lange zoektocht naar geschikte teststoffen en de noodzaak om vanwege het voortschrijdende seizoen de mesocosms tijdig in te richten, was de behoefte aan drie extra controle mesocosms niet bekend toen de mesocosms werden geïnstalleerd. Om een gelijke ontwikkeling in alle mesocosms optimaal te laten verlopen kunnen na aanvang van de acclimatisatieperiode geen extra mesocosms meer worden toegevoegd.

Op grond van literatuurgegevens mocht verwacht worden dat de 'achtergrond concentratie' van 0.1 mg SDS/L tot ecologische effecten zou leiden. Er zijn inderdaad in de controle mesocosms geen aanwijzingen gevonden dat deze dosering de ontwikkeling van de experimentele ecosystemen meetbaar heeft beïnvloed. Het plotseling teruglopen van de vitaliteit van het fytoplankton in alle mesocosms inclusief de controles bij de start van de dosering zou de enige indicatie kunnen zijn dat de gedoseerde hoeveelheid SDS wel een effect heeft gehad. Het kan echter ook een samenloop van omstandigheden betreffen. Een vergelijkbare plotselinge daling van de vitaliteit van het fytoplankton in alle mesocosms werd immers ook op de voorlaatste bemonsteringsdag waargenomen.

Wegens ontbreken van analysemethode is er geen inzicht in gedrag/verspreiding van de nanodeeltjes in de mesocosms. De snel afnemende vertroebeling van de waterkolom nadat de doseringen werden beëindigd suggereert dat het merendeel van de deeltjes niet lang in suspensie blijven. ACVA deeltjes veroorzaken bij dezelfde dosering een iets hogere en langduriger meetbare vertroebeling. Dit is mogelijk het gevolg van de iets kleinere diameter van de ACVA deeltjes (46 nm) t.o.v. de KPS deeltjes $(55 \mathrm{~nm})$. Doordat het volume van een bolvormig deeltjes met de derde macht toeneemt met de diameter heeft een gering verschil in grootte al snel een substantiële invloed op het gewicht. Uitgaande van de mediane deeltjesgrootte kan worden berekend dat er bij hetzelfde doseringsgewicht ca. $70 \%$ meer deeltjes zijn gedoseerd in de ACVA-mesocosms dan in de KPS-mesocosms.

De respons van de mesocosm ecosystemen op de dosering van de nanodeeltjes was beperkt. Naast vertroebeling van het water en een incidentele afwijking van de $\mathrm{pH}$, waren de enige significante verschillen met de controle mesocosms het verlies van lichaamsgewicht van zeepieren in beide behandelingen met ACVA deeltjes en het lagere vleesgewicht van kokkels in beide behandelingen met KPS deeltjes. In beide gevallen zijn de afwijkingen subtiel. Vooral bij de zeepier is sprake van een sterker effect bij de hoge ACVA dosering. Het is opvallend dat deze, in de basis vergelijkbare effecten (groeiremming) door de verschillende typen deeltjes bij de verschillende soorten zichtbaar worden. Wellicht hangt dit samen met de verschillen in blootstelling. De kokkel zal als filterfeeder vooral aan in de waterfase aanwezige deeltjes worden blootgesteld, terwijl voor de bodembewonende zeepier de opname van gesedimenteerde deeltjes de belangrijkste zal zijn. Dit zou op verschil in gedrag kunnen duiden tussen de beide deeltjes.

Naast genoemde statistisch significante verschillen bevat de dataset waarden die een indicatie zouden kunnen zijn voor subtiele effecten die in deze studie niet statistisch onderbouwd konden worden. Dit betreft bijvoorbeeld de iets hogere chlorofyl gehalten die rond dag 13 in beide hoogst gedoseerde behandelingen zichtbaar worden. Dit zou erop kunnen duiden dat deze doseringen op dat moment de efficiëntie verminderen waarmee het zoöplankton en/of de schelpdieren het fytoplankton begrazen. Het feit dat deze situatie slechts kort duurt, mogelijk omdat de nanodeeltjes snel uit de waterkolom verdwijnen, kan verklaren waarom er geen effecten van verminderde voedselopname in de zoöplanktongemeenschap zijn gevonden. Ook worden indicaties gevonden voor een lagere soortenrijkdom van het benthos in de hoog gedoseerde mesocosms aan het eind van de studie, en een lagere conditie index van de alikruiken uit de KPS-2 behandeling. 
Tabel 7 Overzicht van de significante verschillen die op bemonsteringsdagen werden waargenomen tussen de mesocosms behandeld met nano-deeltjes en de controles. Tussen haakjes zijn observaties vermeld die niet statistisch significant zijn, maar mogelijk wel wijzen op subtiele effecten.

\begin{tabular}{|c|c|c|c|c|}
\hline \multirow[b]{2}{*}{ Dag nr. } & \multicolumn{2}{|c|}{ ACVA } & \multicolumn{2}{|c|}{ KPS } \\
\hline & $0.25 \mathrm{mg} / \mathrm{L}$ & $5 \mathrm{mg} / \mathrm{L}$ & $0.25 \mathrm{mg} / \mathrm{L}$ & $5 \mathrm{mg} / \mathrm{L}$ \\
\hline 2 & - & - & - & Troebelheid \\
\hline $4-11$ & - & Troebelheid & - & Troebelheid \\
\hline 13 & - & $\begin{array}{l}\text { Troebelheid; } \\
\text { (Chlorofyl) }\end{array}$ & - & (Chlorofyl) \\
\hline 62 & - & - & $\mathrm{pH}$ & - \\
\hline 67 & Zeepier & Zeepier; (Benthos) & Kokkel & $\begin{array}{l}\text { Kokkel; (Benthos; } \\
\text { Alikruik) }\end{array}$ \\
\hline
\end{tabular}




\section{$5 \quad$ Kwaliteitsborging}

Wageningen Marine Research beschikt over een ISO 9001:2008 gecertificeerd kwaliteitsmanagementsysteem (certificaatnummer: 187378-2015-AQ-NLD-RvA). Dit certificaat is geldig tot 15 september 2018. De organisatie is gecertificeerd sinds 27 februari 2001 . De certificering is uitgevoerd door DNV Certification B.V. 


\section{$6 \quad$ Financiële verantwoording}

Dit onderzoek is mede mogelijk gemaakt door een financiële bijdrage uit het European Maritime and Fisheries Fund (EMFF).

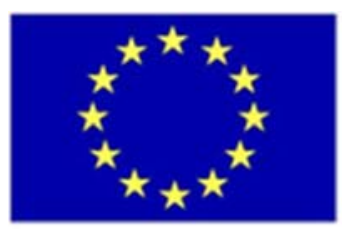




\section{Literatuur}

Carpenter E.J., Smith K.L. (1972): plastics on Sargasso sea-surface. Science 175(4027): 1240-1241.

Collignon A., Hecq J-H., Galgani F., Collard F., Goffart A., (2014): Annual variation in neustonic microand meso-plastic particles and zooplankton in the Bay of Calvi (Mediterranean-Corsica). Marine Pollution Bulletin 79(1-2): 293-298.

Cózar A., Martí E., Duarte C.M., García-de-Lomas J., van Sebille E., Ballatore T.J., Eguíluz V.M., González-Gordillo J.I., Pedrotti M.L., Echevarría F., Troublè R., Irigoien X. (2017): The Arctic Ocean as a dead end for floating plastics in the North Atlantic branch of the Thermohaline Circulation. Science Advances 2017;3:e1600582 8p.

De Jong F.M.W., Brock T.C.M., Foekema E.M., Leeuwangh P. (2008): Guidance for summarizing and evaluating aquatic micro- and mesocosm studies. Guidance document of the Dutch Platform for the Assessment of Higher Tier Studies RIVM Report 601506009/2008A.

Desforges J.-P.W., Galbraith M., Dangerfield N., Ross P.S. (2014): Widespread distribution of microplastics in subsurface seawater, in the NE Pacific Ocean. Marine Pollution Bulletin 79: 94-99.

Foekema, E.M. ; Heuvel-Greve, M.J. van den; Sonneveld, C. ; Hoornsman, G. ; Blanco Garcia, A. (2016): Uitloging en effecten van metalen uit staalslakken beoordeeld in mesocosms. IMARES Wageningen UR, (Rapport / IMARES C063/16) - 102 p.

Frias, J., Otero, V., Sobral, P. (2014): Evidence of microplastics in samples of zooplankton from Portuguese coastal waters. Marine Environmental Research 95: 89-95.

Lozano, R. L.; Mouat, J. 2009. Marine Litter in the North-East Atlantic Region: Assessment and Priorities for Response; KIMO International

Lürling M., Beekman W. (2002): Extractable substances (anionic surfactants) from membrane filters induce morphological changes in the green alga Scenedesmus obliquus (Chlorophyceae).

Environmental Toxicology \& Chemistry 21: 1213-1218.

Thompson R.C., Olsen Y., Mitchell R.P. et al. (2004): Lost at sea: Where is all the plastic?. Science 304(5672): 838-838.

Radix P., Léonard M., Papantoniou C., Roman G., Saouter E., Gallotti-Schmitt S., Thiébaud H., Vasseur P. (1999): Comparison of Brachionus calyciflorus 2-d and Microtox chronic 22-h tests with Daphnia magna 21-d test for the chronic toxicity assessment of chemicals Environmental Toxicology \& Chemistry 18: 2178- 2185. 


\section{Verantwoording}

Rapport nummer: $\mathrm{C} 107 / 17$

Projectnummer: 4315100062

Dit rapport is met grote zorgvuldigheid tot stand gekomen. De wetenschappelijke kwaliteit is intern getoetst door een collega-onderzoeker en het verantwoordelijk lid van het managementteam van Wageningen Marine Research.

Akkoord:

Handtekening:

Datum:

Akkoord:

Handtekening:

Datum:
Dr. N.H.B.M. Kaag

Senior onderzoeker

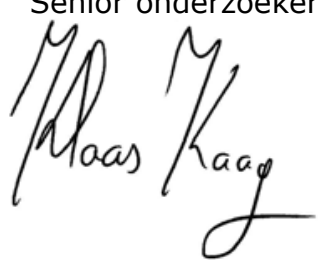

13 december 2017

Dr.ir. T.P. Bult

Director

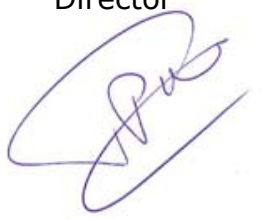

13 december 2017 


\title{
Bijlage 1 Production of two batches polystyrene nanoparticles in request of Marine Research
}

\author{
Project lead: $\quad$ Fresia Alvarado Chacon \\ Wageningen Food and Biobased Research, business unit \\ biobased products \\ Project name: \\ Production of Nanoparticles \\ Client \\ Dr. Edwin Foekema \\ Wageningen Marine Research \\ Experimenter: \\ Remco Simonsz
}

\section{I ntroduction}

Dr. Edwin Foekema approached BBP with the question of producing small plastic particles eventually comparable to natural materials. The proposal from BBP was to produce polystyrene nanoparticles by polymerization in emulsion since size can be controlled very accurately. After several communication emails and telephone calls, and some explorative milling experiments reported on email with date 2404-2017 (see attachment); it was decided to produce two batches of nanoparticles with different charges. Here the details of the experiments are reported.

\section{Materials}

Table 1 Chemicals used for polymerization

\begin{tabular}{|l|l|l|l|l|}
\hline Chemical & Supplier & Purity & Addition & $\begin{array}{l}\text { Reason } \\
\text { addition }\end{array}$ \\
\hline Potasium persulfate (KPS) & Acros organics & $\geq 99 \%$ & & \\
\hline Sodium bicarbonate & Alfa Aesar & $99 \%$ & & \\
\hline $\begin{array}{l}\text { Sodium dodecyl sulfate } \\
\text { (SDS) }\end{array}$ & Sigma Aldrich & $\geq 99 \%$ & & \\
\hline Styrene & Sigma Aldrich & $\geq 99 \%$ & 4-tert-butylcatechol & Inhibitor \\
\hline $\begin{array}{l}\text { 4,4'-Azobis (4-cyanovaleric } \\
\text { acid) (ACVA) }\end{array}$ & Sigma Aldrich & $\geq 98 \%$ & & \\
\hline Sodium hydroxide (NaOH) & Sigma Aldrich & $\geq 99 \%$ & & \\
\hline
\end{tabular}




\section{Methods}

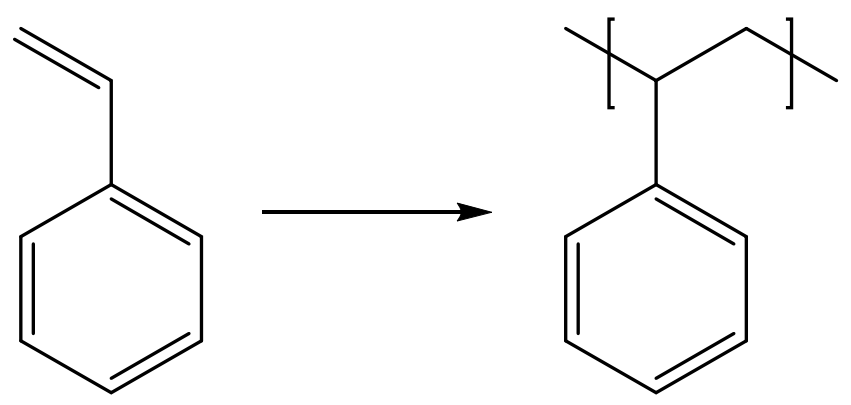

Figure 1 Reaction scheme

Table 2 Concentrations used for batch named KPS

\begin{tabular}{|l|l|l|l|}
\hline Phase & Content phase & Mass (g) & Additional information \\
\hline A & SDS & 5.95 & $2 \mathrm{wt} \%$ based on water \\
\hline & Sodium bicarbonate & 1.25 & $0,25 \mathrm{wt} \%$ based on total \\
\hline & Demineralized water & 262.40 & $90 \%$ of total water content \\
\hline B & KPS & 1.25 & $0,25 \mathrm{wt} \%$ based on total \\
\hline & Demineralized water & 29.15 & $10 \%$ of total water content \\
\hline C & Styrene & 200 & $40 \%$ of total weight \\
\hline & & $\mathbf{5 0 0}$ & Total weight \\
\hline
\end{tabular}

Table 3 Concentrations used for batch named AVCA

\begin{tabular}{|l|l|l|l|}
\hline Phase & Content phase & Mass $(\mathbf{g})$ & Additional information \\
\hline A & SDS & 5.95 & $2 \mathrm{wt} \%$ based on water \\
\hline & Sodium bicarbonate & 1.25 & $0,25 \mathrm{wt} \%$ based on total \\
\hline & Demineralized water & 262.40 & $90 \%$ of total water content \\
\hline B & ACVA & 1.30 & $\begin{array}{l}\text { Same mole ratio as KPS in the } \\
\text { other emulsion }\end{array}$ \\
\hline & NaOH & 0.37 & Mole ratio $1: 2$, ACVA:NaOH \\
\hline & Demineralized water & 29.15 & $\sim 10 \%$ of total water content \\
\hline C & Styrene & 200 & $40 \%$ of total weight \\
\hline & & $\mathbf{5 0 0}$ & Total weight \\
\hline
\end{tabular}

Phase A was weighted in the reactor and the reaction setup (see Figure 2) was built up in a fume hood. Thereafter the present oxygen in the solution was removed by bubbling with $\mathrm{N}_{2}$ gas during 20 minutes. While bubbling the reaction mixture was stirred. Meanwhile phase $B$ was weighted in. After the 20 minutes of $\mathrm{N}_{2}$ bubbling the reaction mixture was heated to $70^{\circ} \mathrm{C}$ by an oil bath. At $70^{\circ} \mathrm{C}$ phase $\mathrm{C}$ was added. After the addition of phase $\mathrm{C}$ the reaction mixture was once again heated to $70^{\circ} \mathrm{C}$. And finally at $70^{\circ} \mathrm{C}$ phase $\mathrm{B}$ was added. The reaction mixture was reacted for 3 hours. The latexes were filtered with a 60 wire mesh filter. The filter and the reactor were washed with some water. 


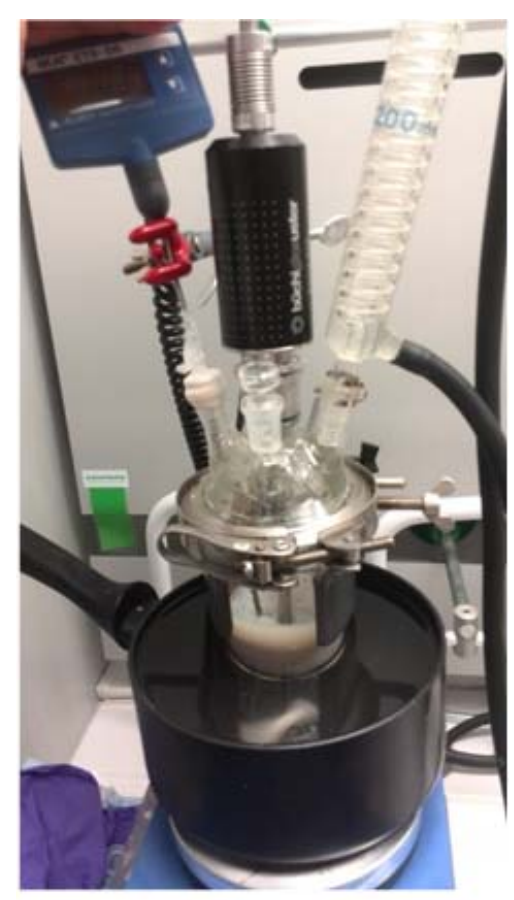

Reactor

Figure 2 Reactor setup

\section{Analysis}

\section{Solid content}

Solid content was measured with the Mettler Moisture Analyzer shown in Figure 3. A latex sample was heated at $105^{\circ} \mathrm{C}$ until the mass was stable for at least 120 seconds.

Results were the following:

KPS: $37.2 \%(+/-0.2 \%)$

ACVA: $35.9 \%(+/-0.2 \%)$

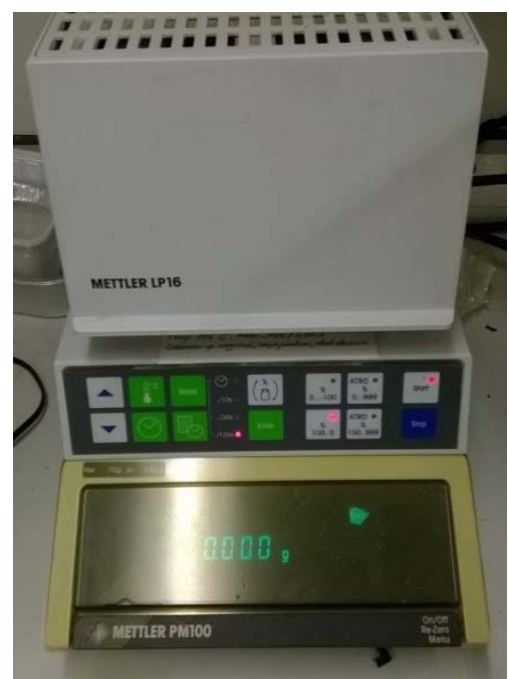

Figure 3 Mettler moisture analyzer

Using these results, the approximate latex content was calculated based on the weight-in values. Results are shown in Table 4 
Table 4 Actual content of the latex solution based on weight-in values

\begin{tabular}{|l|l|l|}
\hline $\begin{array}{l}\text { GRAM PER 100 GRAM } \\
\text { EMULSI E }\end{array}$ & ACVA & KPS \\
\hline Solid content & 35.9 & 37.2 \\
\hline SDS & 1.023 & 1.062 \\
\hline Sodium bicarbonate & 0.215 & 0.223 \\
\hline Demineralized water & 64.1 & 62.8 \\
\hline ACVA/ KPS & 0.223 & 0.223 \\
\hline PolyStyrene & 34.376 & 35.692 \\
\hline NaOH & 0.064 & 0 \\
\hline
\end{tabular}

\section{Particle size distribution}

Particle size was analysed using a Mastersizer instrument from Malvern. Values containing $50 \%$ of the volume are reported here $(D(50))$. In Table 5 , the average of 5 measurements and its standard deviation are reported and the graph is a representative distribution for each sample.

Table 5 Results particle size for the two batches

\begin{tabular}{|c|c|c|}
\hline Batch & $\begin{array}{l}\text { Average } \\
\text { particle } \\
\text { size (nm) }\end{array}$ & Typical particle size distribution \\
\hline ACVA & $46+/-1$ & $\overbrace{\substack{\text { tible) } \\
\text { (1) }}}$ \\
\hline KPS & $55+/-9$ & $\overbrace{\text { ible) }}$ \\
\hline
\end{tabular}




\section{Recommendations}

Gently shake the bottle before taking a sample to obtain a homogenous latex.

\section{Attachment}

Report-milling of PS granulate<smiles>C[C+]1CCC1</smiles>

summary - milling of

particles 24-04-2017.

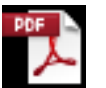

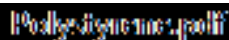


Wageningen Marine Research

T: +31(0)317480900

E: marine-research@wur.nl

www.wur.nl/marine-research

Visitors address

- Ankerpark 271781 AG Den Helder

- Korringaweg 7, 4401 NT Yerseke

- Haringkade 1, 1976 CP IJmuiden
Wageningen Marine Research is the Netherlands research institute established to provide the scientific support that is essential for developing policies and innovation in respect of the marine environment, fishery activities, aquaculture and the maritime sector.

Wageningen University \& Research is specialised in the domain of healthy food and living environment.

The Wageningen Marine Research vision:

'To explore the potential of marine nature to improve the quality of life.'

The Wageningen Marine Research mission

- To conduct research with the aim of acquiring knowledge and offering advice on the sustainable management and use of marine and coastal areas.

- Wageningen Marine Research is an independent, leading scientific research institute.

Wageningen Marine Research is part of the international knowledge organisation Wageningen UR (University \& Research centre). Within Wageningen UR, nine specialised research institutes of Stichting Wageningen Research (a Foundation) have joined forces with Wageningen University to help answer the most important questions in the domain of healthy food and living environment. 